Santa Clara University

Scholar Commons

Economics

Leavey School of Business

$10-1-2014$

\title{
Trends in the Happiness of Single Mothers: Evidence from the General Social Survey
}

John Ifcher

Santa Clara University, jifcher@scu.edu

Homa Zarghamee

Follow this and additional works at: http://scholarcommons.scu.edu/econ

Part of the Economics Commons

\section{Recommended Citation}

Ifcher, John, and Homa Zarghamee. "The Happiness of Single Mothers: Evidence from the General Social Survey." Journal of Happiness Studies J Happiness Stud 15.5 (2014): 1219-238.

The final publication is available at Springer via http://dx.doi.org/10.1007/s10902-013-9472-5.

This Article is brought to you for free and open access by the Leavey School of Business at Scholar Commons. It has been accepted for inclusion in Economics by an authorized administrator of Scholar Commons. For more information, please contact rscroggin@scu.edu. 
Trends in the Happiness of Single Mothers:

Evidence from the General Social Survey

\author{
John Ifcher \\ jifcher@scu.edu \\ Santa Clara University
}

Homa Zarghamee

hzarghamee@scu.edu

Santa Clara University

July 2011

JEL classification codes: I38, D60, H53

Keywords: single mothers, happiness, welfare reform, difference-in-difference, subjective wellbeing, General Social Survey (GSS)

All opinions and errors are those of the authors. The authors contributed equally to this work. 


\begin{abstract}
We study the subjective well being (SWB) of single mothers from 1972 to 2008 using data from the General Social Survey. While past literature has examined the outcomes of single mothers, an investigation of SWB is warranted, since it has been shown that there are potentially large slippages between economic indicators and SWB. Our results indicate that (i) single mothers report being significantly less happy than non-single-mothers, and (ii) this "happiness gap” shrank between 1972 and 2008.
\end{abstract}




\section{Introduction}

Births to unmarried mothers have soared since 1970, growing from approximately 10 percent of all births to over 40 percent; and over 25 percent of all children in the U.S. today live with only one of their parents. Among African Americans, over 70 percent of births are to unmarried women and almost half of all children live with one parent (Grogger and Karoly, 2005; and Grail, 2009). Moreover, single mothers are twice as likely as others to be impoverished (24.6 percent versus 12.5 percent in 2007) and are, on average, less educated and in worse health (Meyer and Sullivan, 2010 and Grail, 2009). Compared to children who live with both parents, children of single mothers are at a higher risk of negative outcomes, including dropping out from high school and giving birth while still a teenager (McLanahan and Sandefur, 1994).

Given the surge in the number of single mothers as well as their challenging circumstances, many policy makers and academics alike have made them the focus of their work. Policy makers have designed and implemented numerous social welfare programs intended to help single mothers, and academics have investigated the causes and effects of single motherhood as well as the effects of programs intended to help them. For example, there is a vast literature that examines the impact of welfare reform, exploring the resulting changes in welfare use, employment, earnings, consumption, health, family structure, and child welfare (reviews include Blank, 2002; Grogger and Karoly, 2005; and Moffitt, 2003). ${ }^{1}$

1 The findings appear to indicate that, at least in the short run, the reforms had the intended effect, reducing welfare use and increasing employment. Further, single mothers' consumption and health do not appear to have been compromised in the process (Meyer and Sullivan, 2008; 
One important outcome, however, has received less attention—-the Subjective Well Being (SWB) of single mothers. A growing body of research, however, suggests that it would be valuable and feasible to conduct such an investigation. It is valuable because economists and policy makers are concerned about individuals' well being, and well being cannot necessarily be measured using economic indicators alone (Diener and Seligman, 2008). Further, a growing number of economists have been using happiness data in their research (Kahneman and Kreuger, 2006). Such data has been shown to be valid and reliable (Gruber and Mullainathan, 2005; and Krueger and Schkade, 2008). For example, many objective measures of well-being are positively correlated with self-reported happiness. Individuals who report being happier are rated to be happier by others (spouses, family members, friends, and associates); absent from work less; more optimistic about the future; more energetic, flexible, and creative; and less likely to need psychological counseling (Frey and Stutzer, 2002). Moreover, Krueger and Schkade (2008) report that SWB measures are reliable enough to warrant their use in across group comparisons.

Three recent working papers have started to explore the SWB of single mothers. All three attempt to determine the impact of welfare reform on single mothers' SWB. Ifcher (2010) and Herbst (2010b) use a difference-in-differences approach and find that single mothers' SWB was greater after welfare reform than before. Ifcher's paper uses the same dataset as the current paper, the GSS, and the same measure of SWB, self-reported happiness; the GSS and its selfand Kaestner and Tarlov, 2006). While some questions remain, including what role the robust economy played (Blank, 2002), it appears that the reforms were a success, at least from the government's perspective. 
reported happiness measure are the most commonly used dataset for studying U.S. SWB. Herbst's paper uses an alternative dataset, the DDB Life Style Survey, and other measures of SWB. The third recent working paper, Herbst (2010a), investigates trends in single mothers' SWB between 1985 and 2005. Like Herbst's other paper, it uses the DDB Life Style Survey and other measures of SWB (other than self-reported happiness). In it, Herbst constructs an index of SWB, which is a composite of, among other indices, a measure of life satisfaction and measures of physical and mental health. Trends for single mothers are compared to trends for both single non-mothers and married mothers. Herbst finds that single mothers' life satisfaction appears to have increased both absolutely and relatively, but that single mothers' physical and mental health has declined both absolutely and relatively. Hence the trend in the composite SWB index of single mothers is statistically indistinguishable from those of the comparison groups. ${ }^{2}$ The current paper adds to this emerging literature by examining trends in single mothers' SWB over an extended time frame, from 1972 to 2008.

Two other papers are highly relevant to the current paper, both of which use the GSS and its happiness measure to explore SWB trends (Stevenson and Wolfers, 2009 and 2010). The first paper investigates trends in the SWB of women in the U.S. between 1972 and 2006. It finds that women's happiness has declined, both absolutely and relative to men, during this period. The second paper investigates trends in the SWB of African Americans in the U.S. between 1972 and ${ }^{2}$ Herbst's definition of single mothers differs slightly from the definition we will be using: we restrict single mothers to mothers between the ages of 18 and 45 who have at least one child under age 18 in their households. Herbst uses the same definition, but restricts ages to between 18 and 60. 
2008. It finds that African Americans' happiness has increased, both absolutely and relative to Whites, during this period. Each paper explores potential reasons for the observed trend, juxtaposing the trend with societal and demographic changes that occurred during the period. These results are directly relevant to the current paper since all single mothers are women and since single mothers are more likely to be African American than are non-single-mothers ${ }^{3}$ (33.2 percent versus 10.8 percent in the current sample).

In this paper, the use of happiness data is extended to the study of single mothers. Specifically, data from the GSS is used to study the happiness of single mothers over the last four decades. The results appear to indicate that single mothers are a very unhappy group. The happiness gap between single mothers and non-single-mothers is large and reflects a shift in the entire distribution of self-reported happiness. That is, single mother are both more likely to report being "not too happy" and less likely to report being "very happy" than are non-singlemothers. The results also indicate that the happiness gap between single mothers and non-singlemothers shrank between 1972 and 2008. The paper unfolds as follows: the next section discusses the data; the third section explores the unhappiness of single mothers; the fourth section examines whether the happiness gap changes between 1972 and 2008; and the fifth section discusses the results.

\section{Data}

The data for this study comes from the GSS. The GSS contains a set of demographic and attitudinal questions including those that would traditionally be of interest to economists, for

3 “Non-single-mothers" refers to all people, including men, who are not single mothers. 
example, regarding income and educational attainment, as well as a range of other questions regarding religion, politics, and personal values. The survey has been administered to a nationally representative sample of between 1,372 and 4,510 U.S. households every year, or every other year, since 1972 .

The GSS is of special interest because it includes questions regarding respondents’ SWB. Specifically, it asks the standard "happiness” question: “Taken all together, how would you say things are these days -- would you say that you are very happy, pretty happy, or not too happy?” The happiness question has remained intact since 1972; thus, the GSS is well suited to studying trends in self-reported happiness (Stevenson and Wolfers, 2009). However, there have been other changes to the survey and the sampling that might impact self-reported happiness trends. Stevenson and Wolfers (2008, 2009, and 2010) have written a series of papers examining trends in SWB using the GSS. We closely follow their methodology for creating a consistent measure of self-reported happiness. This includes: (i) adjusting for changes in the question that directly preceded the happiness question in the 1972 and 1985 GSS (using split-ballot experiments); (ii) dropping the Black oversample from the 1982 and 1987 GSS; (iii) dropping surveys that were conducted in Spanish that could not have been completed in English (in the 2006 GSS only); and (iv) using the GSS weight WTSSALL to help ensure that the sample is nationally representative (see Appendix A of Stevenson and Wolfers (2008) for additional details).

Single mothers are identified using the following demographic characteristics: gender, marital status, age, number of children, and number of children (less than 18 years old) that live in the respondent's household. To be considered a single mother a respondent must: (i) be female, (ii) be single (this includes women who are widowed, divorced, separated, or never 
married), (iii) be at most 45 years old, (iv) have children, and (v) report at least one child living in the household. The reason for some of these criteria is self-evident—for example, being female and single - the reason for other criteria warrants further explanation. In particular, respondents were not asked the age of their children or whether their children lived with them. Thus, a single female with a child could easily be a grandparent, a non-custodial parent, or an empty nester. In an attempt to focus the analysis on single mothers who are primary custodial parents, single females must (i) have at least one child, (ii) report at least one child living in their household, and (iii) be at most 45 years old, to be identified as a single mother in the study. Finally, all respondents who are over 45 years old are dropped from the analysis so that nonsingle-mothers in the sample are comparable to single mothers in the sample.

This leaves 26,005 respondents, of whom 2,799 are identified as single mothers. The average happiness of all respondents is 2.211 where "not too happy” (10.6 percent of responses), “pretty happy” (57.6 percent of responses), and “very happy” (31.7 percent of responses) are

coded as one, two, and three, respectively [see Column (1) of Table I]. Respondents are likely to be high school graduates, white, in good or excellent health, and employed.

\section{The Unhappiness of Single Mothers}

Single mothers are an unhappy group. Their average happiness is 1.966 . That is 0.265 fewer happiness points than the average for all non-single-mothers (2.231). This happiness gap is the result of being (i) less likely to report high levels of happiness (“very happy”) and (ii) more likely to report low levels of happiness ("not too happy”). Single mothers are 15.2 percentage points, or 46 percent, less likely to report being “very happy” and 11.4 percentage points, or 111 
percent, more likely to report being "not too happy” than the average non-single-mother [compare Columns (2) and (3) of Table I]. A difference of means test reveals that each of these differences is statistically significant. Single mothers are also significantly less happy than the following comparison groups: all women (who are not single mothers), all single childless women, and all married mothers.

\section{The magnitude of the single mother happiness gap}

To illustrate the magnitude of the single mother happiness gap one can consider the impact of known happiness shocks. For example, it is well known that in cross-sectional studies individuals with higher income report being happier than individuals with lower income. The happiness gap between respondents with real family income per household equivalent in the top quartile (above \$41,801 in 2008 USD) and the bottom quartile (below \$15,011 in 2008 USD) is

0.24 points. This happiness gap is a little bit smaller than the single mother happiness gap. Interestingly, this income differential (the inter-quartile range) is substantially larger than the income differential between single mothers and non-single-mothers ( $\$ 26,790$ versus $\$ 17,040$ ). Thus, single mothers are less happy than would be predicted simply given their family income. Stevenson and Wolfers (2010) also report that Blacks are substantially less happy than Whites on average. The happiness gap between Black and White respondents in the sample is 0.25 points. Again, this is slightly smaller than the single mother happiness gap. Finally, the unemployment rate, a known happiness shock, would need to increase by over 10 percentage points to reduce happiness by the single mother happiness gap (Stevenson and Wolfers, 2009). 


\section{Adjusting for exogenous and endogenous controls}

The single mother happiness gap is perhaps not surprising after one compares single mothers' demographic characteristics to those of the average non-single-mother. That is, single mothers are significantly more likely to have characteristics associated with low levels of happiness (Frey and Stutzer, 2002). For example, they are more likely than the average non-single-mother to be single (100 percent versus 38.3 percent), in poor or fair health (17.7 percent versus 10.9 percent), and nonwhite (40 percent versus 16.5 percent); further, their average real family income per household equivalent is approximately half that of the typical respondent (\$34,130 versus $\$ 17,090)$.

To test whether one can eliminate the happiness gap by controlling for single mothers' demographic characteristics, an equation of the following form is estimated:

$$
\text { Happiness }_{i}=\beta^{\text {SingleMother }} \text { SingleMother }{ }_{i}+\alpha \bullet X_{i}+\varepsilon_{i}
$$

where SingleMother $r_{i}$ is a dummy variable that equals one if individual $i$ is identified as a single mother and zero otherwise; and $X_{i}$ is a vector of demographic characteristics for individual $i$ including gender, age, race, native born, parental status (mother versus not mother), marital status (single versus not single), educational attainment, health, family income, and region. Equation (1) is estimated using an ordered probit; robust standard errors are calculated by clustering the observations by year.

Estimating equation (1) without covariates, the coefficient on SingleMother is negative, large, and highly statistically significant $(b=-0.488$, s.e. $=0.020)$. This indicates that single 
mothers are significantly less happy on average than are non-single-mothers [see Column (1) of Panel (A) of Table II]. Adding controls for demographic characteristics that are clearly exogenous— that is, gender, age, race, and native born—does not materially affect the coefficient $(\mathrm{b}=-0.512$, s.e. $=0.021)$ [see Columns (2) of Panel $(\mathrm{A})$ of Table II]. Thus, even after controlling for exogenous characteristics including being nonwhite (which is known to be associated with reduced happiness), the coefficient on single mother is negative, large and highly statistically significant.

The results materially change, however, when one adds controls for demographic characteristics that are not clearly exogenous—-mother, single, educational attainment, health status, work status, number of children, a quartic in log real family income per household equivalent, and region ${ }^{4}$. Now the coefficient on single mother is indistinguishable from zero $(b=$ -0.029 , s.e. $=0.028)[$ see Columns (3) of Panel (A) of Table II]. Thus, it appears that the unhappiness of single mothers can be explained by life circumstances.

To determine which endogenous control variables are most important in explaining the unhappiness of single mothers, we drop each from the analysis one at a time. The most important control variable by far is single. When it is dropped from the ordered probit (and all other covariates are included) the coefficient on single mother returns (almost) to its prior magnitude and significance $(b=-0.436$, s.e. $=0.030)$ [see Columns $(4)$ of Panel $(A)$ of Table II]. The next most important covariate is the number of children a respondent has. However,

${ }^{4}$ This distinction between exogenous and endogenous demographic characteristics follows the approach used by Stevenson and Wolfers (2009). 
dropping this covariate does not return the coefficient on single mother to its former magnitude $(b=-0.054$ versus $b=-0.512)$, nor to its statistical significance $(t=-1.84$ versus $t=-24.3$ ). Thus, one control variable, single, is driving the coefficient on single mother to zero when all covariates are included. This indicates that the unhappiness of single mothers is mostly explained by their being single; and not by other endogenous control variables. Further, there does not appear to be a measureable, additional cost associated with being a single mother beyond their demographic characteristics. Care must be taken, however, when interpreting this finding as the control variables are not exogenous. Thus, one cannot claim that a single mother's life circumstances cause her to be unhappy or vice versa. For example, it might be that unhappy mothers are more likely to be single. Finally, the coefficients on race, single, health, and income are as expected: being Black, single, and in poor or fair health are each associated with lower happiness as is having low income [see Table III].

\section{The distribution of happiness: reports of being "very happy" and "not too happy"}

The single mother happiness gap could result from single mothers being less likely to report being “very happy,” more likely to report being "not too happy,” or both (in comparison to nonsingle-mothers). To investigate, equation (1) is estimated using a probit regression in which the dependent variable indicates that a respondent reports being "very happy” or "not too happy.” Again, robust standard errors are calculated by clustering the observations by year.

Estimating the "very happy” probit with no covariates or with the exogenous covariates, the coefficient on single mothers is negative and highly statistically significant, indicating that single mothers are less likely to report being "very happy” than are non-single-mothers [see 
Columns (5) and (6) of Panel (A) of Table II]. Including the endogenous covariates has a similar impact as it did previously. That is, when all covariates are used, the coefficient on single mother is indistinguishable from zero; and when all controls are used except single, the coefficient returns (almost) to its prior magnitude and significance level [see Columns (5) to (8) of Panel (A) of Table II]. The results are similar when estimating the "not too happy" probit except that the sign of all coefficients is positive. This indicates that single mothers are more likely to report being "not too happy" than are non-single-mothers [see Columns (9) to (12) of Panel (A) of Table II]. In summary, the entire distribution of happiness is lower for single mothers than it is for non-single-mothers.

\section{Other comparison groups}

To further explore the single mother happiness gap, the sample is restricted as follows: first, to women; second, to single women; and third, to mothers. The coefficients on single mother remain largely the same when the first restriction is imposed [see Panel (B) of Table II]. Thus, single mother appear just as an unhappy in comparison to all women as they do in comparison to all respondents. However, the coefficients on single mother decrease in magnitude with the second restriction and increase in magnitude with the third restriction [see Panels (C) and (D) of Table II]. This indicates that single mothers appear less unhappy when compared to single childless women and more unhappy when compared to married mothers. This is not surprising, since being single has a large negative influence on happiness. 


\section{Trends in the Unhappiness of Single Mothers}

To investigate whether the single mothers happiness gap has increased or decreased since 1972, an equation of the following form is estimated:

$$
\begin{aligned}
& \text { Happiness }_{i}= \beta^{\text {SingleMotherTimeTrend }_{\text {SingleMother }}} *\left(\left(\text { Year }_{i}-1972\right) / 100\right)+ \\
& \beta^{\text {NotSingleMotherTimeTrend }} \text { NotSingleMother }_{i} *\left(\left(\text { Year }_{i}-1972\right) / 100\right)+ \\
& \beta^{\text {SingleMother }} \text { SingleMother } \\
& i
\end{aligned}
$$

where Year $_{i}$ is the year in which the GSS was administered for respondent $i$; and all other variables are defined as before. The coefficients on the single-mother and non-single-mother

time trend, $\beta^{\text {SingleMotterTimeTrenl }}$ and $\beta^{\text {NotSingleMtherTimeTrend }}$, estimate the change in happiness that the respective group experiences over a century. The difference between the two time trend coefficients, $\left(\beta^{\text {SingleMoterTimeTrenl }}-\beta^{\text {NotSinglemstherTime Fend }}\right)$, estimates the change in single mothers' happiness relative to non-single mothers over a century (Stevenson and Wolfers, 2009 and 2010). Equation (2) is estimated using an ordered probit; robust standard errors are calculated by clustered the observations by year.

\section{The single mother happiness gap has declined}

Figure I illustrates the average happiness of single mothers, non-single-mothers, and female nonsingle-mothers between 1972 and 2008. Two trends appear evident: first, single mothers appear to have become happier during this period, and second, the gap between the happiness of single mothers and (female) non-single-mothers is smaller in 2008 than in 1972. 
Estimating equation (2) without covariates, the single mother time trend coefficient is positive and marginally statistically significant $(b=0.447$, s.e. $=0.247$ ), indicating that single mothers became happier on average between 1972 and 2008 [See Column (1) of Panel (A) of Table IV]; the non-single-mother time trend coefficient was small, negative, and insignificant, indicating that there was not a linear time trend for non-single-mothers between 1972 and 2008. The difference between the time trends was positive and fully statistically significant $(b=0.480$, s.e. $=0.222$ ), indicating that single mothers became happier relative to non-single-mothers between 1972 and 2008. The time trend coefficients remain largely the same when equation (2) is estimated using exogenous control variables—age, gender, native born, and race [See Column (2) of Panel (A) of Table IV]. Thus it appears that single mother became happier-both absolutely and relatively—between 1972 and 2008.

Controlling for endogenous control variables_-"life circumstances”-again materially changes the results; and again, a lone endogenous control variable—single—has the largest impact by far. Estimating equation (2) with all covariates except single, the single mother time trend coefficient is positive but not significant $(b=0.258$, s.e. $=0.212)$; however the difference between the time trends remains positive and significant $(b=0.434$, s.e. $=0.189)$, indicating that single mothers became relatively happier between 1972 and 2008 [See Column (3) of Panel (A) of Table IV]. Interestingly, the non-single-mother time trend is now negative and marginally significant $(b=-0.176$, s.e. $=0.105)$, indicating that non-single-mother appear to have become less happy during this period. Controlling for being single, eliminates all statistical significance for any of the coefficients of interest [See Column (4) of Panel (A) of Table IV]. However, the 
single mother time trend coefficient and the difference between the time trends both remain positive.

The other coefficients from estimating equation (2) are unsurprising and are in line with results from prior happiness research. The coefficients on black, male, poor and fair health, single, and unemployed are negative and statistically significant; and the coefficient on excellent health is positive and statistically significant [see Table V]. Finally, the coefficient on the first term of the quartic in family income is positive and the coefficient on the second term is negative.

\section{Restricting the sample}

To further explore the time trend in the single mother happiness gap, the sample is restricted as before: first, to women; second, to single women; and third, to mothers. When the sample is restricted to female respondents, the time trend coefficients grow in magnitude and some grow in significance [see Panel (B) of Table IV]. Of particularly importance, the difference between the time trends is positive and significant for all specifications. Thus, the single mother happiness gap declined (relative to women) regardless of whether one includes exogenous or endogenous control variables. That the single mother happiness gap declines more when one limits the analysis to women is not surprising since Stevenson and Wolfers (2009) found that female happiness—both absolutely and relative to men—was declining during this period. Our result demonstrates that it was a subset of women — non-single-mothers-who experienced a decline in happiness during this period. 
Further restricting the sample to single women magnifies the coefficients. Specifically, the differences between the time trends are larger, and now, highly statistically significant ( $\mathrm{p}<$ 0.01) regardless of which control variables are used [see Panel (C) of Table IV]. Finally, restricting the sample to mothers eliminates most of the statistically significant coefficients [see Panel (D) of Table IV]. The single-mother time trend coefficient and the difference between the time trend coefficient remain positive but are now insignificant, indicating that relative to married mothers, single mothers did not become happier between 1972 and 2008.

The sample is also restricted by time period to determine if the reduction in the single mother happiness gap occurred throughout the period. Specifically, equation (2) is estimated separately using the 1972 to 1989 GSS and using the 1990 to 2008 GSS. The results indicate that the reduction in the single mother happiness gap occurred in the first period but not in the second. The difference in time trend coefficient is larger for the first period than for the entire period; and insignificant for the latter period for all specifications [see Table VI].

\section{Trends in the distribution of happiness}

The reduction in the single mother happiness gap could result from single mothers becoming more likely than the comparison group to report being “very happy,” less likely to report being "not too happy," or both. To investigate, equation (2) is estimated using a probit regression in which the dependent variable indicates that a respondent reports being "very happy" or "not too happy.” Again, robust standard errors are calculated by clustered the observations by year.

The results indicate that the reduction in the single mother happiness gap is due to a decrease in reports of being "not too happy," and not necessarily due to an increase in reports of 
being "very happy." The "not too happy" difference in time trend coefficients is negative in all specifications and is statistically significant in three out of four specifications, indicating that single mothers become less likely, relative to non-single-mothers, to report being "not too happy” between 1972 and 2008 [see Columns (5) through (8) of Panel (A) of Table VII]. When the sample is restricted to women or to single women, the "not too happy" difference in time trend coefficients is negative and statistically significant in all specifications [see Columns (5) through (8) of Panels (B) and (C) of Table VII]. In contrast, most of the "very happy" difference in time trend coefficients are positive but not statistically significant [see Columns (1) through (4) of Panels (A) through (C) of Table VII].

\section{Subgroups}

To investigate whether the decline in the single mother happiness gap occurred for all single mothers or certain subgroups, the single mother time trend, the non-single-mother time trend, and the single mother indicator variable are each interacted with the following: age categories (between 18 and 26, 27 and 36, or 37 and 45); educational attainment (less than high school, high school, or more than high school); employment status (employed full- or part-time, or not employed); marital status (divorced, separated, or never married); race (black or white); age of youngest child (between 0 and 6, 7 and 12, or 13 and 17); and presence of at least one other adult in the same household ${ }^{5}$. This enables us to estimate a separate single mother time trend for each

\footnotetext{
${ }^{5}$ The relationship between the single mother and other adults living in the same household cannot be determined from the data. For example, they could be her older child, parent, romantic partner, relative, or roommate.
} 
subgroup, for example, a time trend for single mothers who are employed and for those who are not. In the tables that follow, time trends are presented that were estimated with all respondents and with female respondents only.

The categories with highly variant time trends across subgroups are educational attainment, employment status, age of youngest child, and presence of other adults in the household. For example, the difference in time trend coefficients are substantially larger for respondents who did not complete high school than for respondents who completed more than high school [see Table VIII]. In fact, the difference in time trend coefficients are mostly negative but not statistically significant for respondents who completed more than high school. This indicates that the single mother happiness gap narrowed for single mothers with low levels of education, but not for single mothers with high levels of education. The difference in time trend coefficients are also substantially larger for respondents who are not employed than for respondents who are employed [see Table IX]. This indicates that the single mother happiness gap narrowed more for single mothers who do not work than for single mother who do work.

The single mother happiness gap also narrowed more for women raising young children (the youngest child is less than 6 years of age) than for women raising older children. Table $\mathrm{X}$ shows that the magnitude of the difference in time trend coefficients gets smaller as the age of the youngest child increases. Indeed, while not statistically significant, the difference in time trend coefficients for women whose youngest child is between 13 and 17 is negative, indicating that single mothers in this subcategory have fared worse over time than their non-single-mother counterparts. Lastly, Table XI reveals that the single mother happiness gap has narrowed substantially for women who do not live with another adult. This is because, in this subcategory, 
single mothers have gotten substantially happier over time, while non-single-mothers have gotten significantly less happy over time. The difference in time trend coefficients for those with at least two adults in the household is not statistically significant in any specification, but is, in all cases, positive.

While the difference in time trend coefficients are not variant across marital statuses, the results are of interest for a different reason. Now the non-single-mother time trend coefficients are negative, very large, and frequently statistically significant [see Panels (B) through (D) of Table XII]. This indicates that unmarried non-single-mothers became less happy between 1972 and 2008. Consequently, single mothers became happier during this period relative to unmarried non-single-mothers. Finally, there is no consistent pattern across races [see Table XIII] or age categories [see Table XIV].

\section{Discussion}

The results appear to indicate that single mothers are less happy than non-single-mothers, but that this single mother happiness gap shrank between 1972 and 2008. Below, we will discuss possible explanations for the observed trends: changes to social welfare programs, compositional shifts in single motherhood, and reduced stigma. Again, it should be noted that it is the trends themselves, not explanations for them, which is the focus of this paper. We leave it to future research to more firmly establish causation.

\section{Changes to social welfare programs}


During the time period studied, there were substantial changes to U.S. social welfare programs, some of which were specifically designed to help single mothers. A natural question arises: were these changes responsible for the increased happiness of single mothers? As noted in the introduction, Ifcher (2010) and Herbst (2010b) both explicitly set out to determine the effect of welfare reform on the SWB, and both found a significant positive effect. Further, Herbst (2010a) attributes the positive trend in single mother's SWB both absolutely and relative to married women and single, childless women to reformed social welfare programs. Assuming that reforms did in fact significantly positively impact the SWB of single mothers, there is reason to believe that these reforms are not solely responsible for the observed trends. Were they, then the upward trend in single mothers' SWB should be strongest post-1990, since that is when the most major reforms, including the 1996 Personal Responsibility and Work Opportunity Reconciliation Act (PWRORA), occurred. As shown above, though, splitting the sample pre- and post-1990 reveals that the significant gains to single mothers' SWB occurred in the earlier period.

\section{Increased labor force participation}

In addition to increased rights and benefits for working mothers, discrimination against women in the work place dropped, and labor force participation rates for women, in general, and mothers, in particular, skyrocketed. Therefore, one might conclude that increases in the labor force participation rate of single mothers drove the increase in happiness. However, during the same period, Stevenson and Wolfers (2009) find that all women became less happy, on average. ${ }^{6}$

\footnotetext{
${ }^{6}$ Using the same data set (minus the 2008 wave), Stevenson and Wolfers (2009) report a negative trend in single mothers' SWB — the opposite of our result. There are three main reasons
} 
If increased labor force participation were the driving force behind single mothers' increased happiness, then it should have driven all women to become happier? Further, the increase in happiness among single mothers was greater for single mothers who did not work than for single mothers who did. Hence increased labor force participation alone is unlikely to be responsible for the trend in single mothers' SWB.

\section{Compositional shifts in single motherhood}

\section{Changing partnerships}

In the period from 1972 to 2008, the composition of the American household dramatically changed. The surge in single motherhood was accompanied by comparable surges in—among others—single fatherhood, cohabitating unmarried parents, and same-sex couples. A potential explanation for the rise in SWB among single mothers could be related to compositional shifts related to these other changes. For example, relative to 1972, the category "single mother" in 2008 may be less likely to represent a woman raising her children alone and more likely to represent a woman raising her children with a cohabitating long-term partner of either sex. Assuming the financial and psychological stress of child-rearing is abated with a partner, the rise in single mothers' SWB may be attributable to the changing meaning of being single. This

for this: (1) their statistic includes whites only, and blacks—especially black women—had significant increases in SWB during this time period; (2) our definition of single mothers only includes women under the age of 45, while they consider all ages; and (3) our definition of single mothers only includes mothers with at least one child under the age of 18 living in the same household, while they do not have any such restriction. 
interpretation is also supported by the lack of a significant difference between the SWB-trends of single mothers and single childless women. However, as noted above, Table XI shows that single women raising their children with no other adults in the household have become happier over the past forty years, both absolutely and relative to non-single-mothers who do not live with another adult. Single mothers who live with at least one other adult have neither become happier absolutely nor relative to their non-single-mother counterparts over time. ${ }^{7}$

\section{Shared child-rearing}

The meaning of "single mother" may have also changed over the studied period as a result of changing custodial and child-rearing arrangements. Before 1973, traditionally only one of a child's divorced parents—usually the mother—had custody of the child, while the other parent was granted specific visitation rights. In 1973, Indiana enacted the first law favoring joint custody; by 1984, more than half, and by 2003, almost all the states had followed suit. This is important because, prior to 1973, only one of a child's divorced parents would be categorized as a single parent in the data. With joint, custody, however, both could. If the benefits of shared custody outweigh its costs—regular contact with an ex-husband, for example—-then the observed upward trend in single mothers' SWB would be predicted. This effect need not be restricted to divorced single parents, as the normalization of shared child-rearing between exes may have also

${ }^{7}$ The proportion of single mothers who live with at least one other adult has stayed roughly constant at approximately 0.32 over the sample period. However, the proportion of all households with at least two adults has steadily declined over the sample period, from roughly 0.92 in 1972 to 0.73 in 2008. 
extended to the never-married over the last 40 years. Indeed, in the GSS data, single fathers (who have never been married) make up only $0.60 \%$ (0.48\%) of the population in 1972 and 5.6\% (3.2\%) of the population in 2008.

Single motherhood by choice

There is reason to believe that the incidence of intentional single motherhood increased between 1972 and 2008. First, abortion was federally legalized in 1973. In the extreme, if all post-1993 unwelcome pregnancies were aborted, then there would be no mothers of unwanted children in the sample after 1991, as the children born in 1973 would be 18 . Such a reduction in unwanted pregnancies would not only predict an upward trend in the SWB of single mothers - the overwhelming majority of abortions are performed on single women ${ }^{8}$ — but it would also predict a plateau in the SWB of single mothers after 1991 and a stronger narrowing of the single mother happiness gap for mothers of younger children than for mothers of older children, both of which are consistent with our findings. Further, legalized abortion would likely increase the SWB of single mothers and single childless women alike: the former group would be more likely to consist of single mothers by choice, and the latter group would enjoy increased freedom.

Moreover, the number of single women has increased over the studied time period, and, importantly, so has their educational attainment. In the GSS sample, the share of single mothers

${ }^{8}$ Using data from 1980, Gruber et al (1999) find that the "marginal child” not born as a result of abortion legalization would be $60 \%$ more likely to be in a single-parent household than the average born child. 
with more than a high school education was $14.9 \%$ in 2008 , up from $4.3 \%$ in 1972 . According to Schmidt (2007), while the birthrate for single women with less than a college education increased by 60\% between 1980 and 2000, the birth rate for single college-educated women increased by $145 \%$. If more educated single mothers are more likely to be single mothers by choice, then growth in the population of educated single mothers could explain some of the upward SWB trend for single mothers - though it cannot be the sole explanation since the upward SWB trend held for all educational subgroups.

\section{Stigma}

Society's attitudes toward single mothers evolved during this period as well. Although there is inherently a dearth of evidence, there is reason to believe that at the start of the studied period, in 1972, single mothers — both welfare recipients and not-were subject to considerably more stigmatization than in 2008, the end of the studied period. Circumstantial evidence ranges from Reagan’s famed use of the term “welfare queen” in 1976 to the sterilization under North Carolina eugenics laws of single mothers seeking welfare as late as 1974. Unfortunately, such stigmatization is not wholly a thing of the past. A Pew Research poll asked Americans whether they thought upward trends in the following populations were "good for society," "bad for society,” or “make no difference”: single mothers without a male partner, unmarried parents, gay and lesbian parents, unmarried cohabitating couples, mothers employed outside the home, interracial couples, and childless women. Single motherhood was by far the most negatively assessed: 69\% of respondents thought it was bad for society; unmarried parents and unmarried cohabitating couples were the next most frowned upon, each considered bad for society by $43 \%$ of respondents (Morin, 2011). That said, the current stigmatization of single mothers is likely 
lower than in 1972, as evidenced by, if nothing else, the increase in the incidence of single motherhood. And with this reduced stigmatization, the SWB of single mothers would be expected to rise, consistent with our findings.

\section{Conclusion}

Single mothers are substantially less happy than non-single-mothers. They are both more likely to report being "not too happy” and less likely to report being "very happy” than non-singlemothers. This substantial gap is present even when one controls for all demographic variables other than being single. Further, the results indicate that the single mother happiness gap shrank between 1972 and 2008. Most of the shrinkage appears to have occurred in the first half of the period, between 1972 and 1989, and was strongest for single mothers who are not employed, who did not complete high school, whose youngest child is under age 6, and who do not cohabitate with another adult. 


\section{References}

Blank, Rebecca. 2002. "Evaluating Welfare Reform in the United States." Journal of Economic Literature, 40(4): 1105-1166.

Diener, Ed, and Martin E. P. Seligman. 2008. "Beyond Money: Toward an Economy of WellBeing." Psychological Science In The Public Interest, 5(1): 1-31.

Frey, Bruno S, and Alois Stutzer. 2002. Happiness and Economics. Princeton, NJ: Princeton University Press.

Grail, Timothy S. 2009. “Custodial Mothers and Fathers and Their Child Support: 2007.” U.S. Census Bureau Report P60-237. November 2009.

Grogger, Jeffrey, and Lynn A. Karoly. 2005. Welfare Reform: Effects of a Decade of Change. Cambridge, Massachusetts: Harvard University Press.

Gruber, Johnathan, Phillip Levine, and Douglas Steiger. 1999. “Abortion Legalization and Child Living Circumstances: Who is the “Marginal Child”? Quarterly Journal of Economics, 114(1): 263-91.

Halla, Martin. 2009. “The Effect of Joint Custody on Marriage and Divorce.” IZA Discussion Paper No. 4314.

Herbst, Chris. 2010a. “Footloose and Fancy Free? Two Decades of Single Mothers’ Subjective Well-Being.” Working Paper.

Herbst, Chris. 2010b. "Welfare Reform and the Subjective Well-Being of Single Mothers.” Working Paper.

Ifcher, John. 2010. “The Happiness of Single Mothers after Welfare Reform.” Working Paper. 
Kaestner, Robert, and Elizabeth Tarlov. 2003. "Changes in the Welfare Caseload and the Health of Low-Educated Mothers.” Journal of Public Analysis and Management, 25(3): 623643.

Kahneman, Daniel, and Alan B. Krueger. 2006. "Developments in the Measurement of Subjective Well-Being." Journal of Economic Perspectives, 20(1): 3-24.

Krueger, Alan B., and David A. Schkade. 2008. “The Reliability of Subjective Well-Being Measures.” Journal of Public Economics, 92(8-9): 1833-1845.

McLanahan, Sara, and Gary D. Sandefur. 1994. Growing up with a single parent: what hurts, what helps. Cambridge, Massachusetts: Harvard University Press.

Meyer, Bruce D., and James Xavier Sullivan. 2010. "Further Results On Measuring the WellBeing of the Poor Using Income and Consumption.” The Harris School of Public Policy Studies Working Paper \#07.19.

Meyer, Bruce D., and James Xavier Sullivan. 2008. "Changes in the Consumption, Income, and Well-Being of Single Mother Headed Families." The American Economic Review, 98(5): 2221-41.

Moffitt, Robert A. 2003. Means-Tested Transfer Programs in the United States. Chicago, IL: The University of Chicago Press.

Morin, Rich. 2011. “The Public Renders a Split Verdict On Changes in Family Structure.” Pew Social \& Demographic Trends Reports, Pew Research Center. http://pewsocialtrends.org/2011/02/16/the-public-renders-a-split-verdict-on-changes-infamily-structure/2/ 
Schmidt, Lucie. 2007. "Murphy Brown Revisited: Human Capital, Search and Nonmarital Childbearing Among Educated Women.” Working Paper.

Stevenson, Betsey, and Justin Wolfers. 2008. "Happiness Inequality in the United States.” Journal of Legal Studies, 37(2): S33-79.

Stevenson, Betsey, and Justin Wolfers. 2009. “The Paradox of Declining Female Happiness.” American Economic Journal: Economic Policy, 1(2): 190-225.

Stevenson, Betsey, and Justin Wolfers. 2010. "Subjective and Objective Indicators of Racial Progress.” Working paper. 
Table I: Demographic Characteristics

\begin{tabular}{|c|c|c|c|c|c|c|}
\hline & $\begin{array}{l}\text { All } \\
\text { (1) }\end{array}$ & $\begin{array}{l}\text { Single Mothers } \\
\text { (2) }\end{array}$ & $\begin{array}{l}\text { All Except Single } \\
\text { Mothers } \\
\text { (3) }\end{array}$ & $\begin{array}{l}\text { All Women Except } \\
\text { Single Mothers } \\
\text { (4) }\end{array}$ & $\begin{array}{l}\text { Single Childless } \\
\text { Women } \\
\text { (5) }\end{array}$ & $\begin{array}{l}\text { Married Mothers } \\
\text { (6) }\end{array}$ \\
\hline \multicolumn{7}{|l|}{ Subjective well-being } \\
\hline Average happiness* & $2.211(0.004)$ & $1.966(0.013)$ & $2.231(0.004)$ & $2.281(0.006)$ & $2.160(0.012)$ & $2.330(0.008)$ \\
\hline Very happy & $0.317(0.003)$ & $0.177(0.008)$ & $0.329(0.003)$ & $0.365(0.005)$ & $0.268(0.009)$ & $0.399(0.007)$ \\
\hline Pretty happy & $0.576(0.003)$ & $0.611(0.010)$ & $0.573(0.003)$ & $0.552(0.005)$ & $0.625(0.010)$ & $0.531(0.007)$ \\
\hline Not too happy & $0.106(0.002)$ & $0.212(0.009)$ & $0.098(0.002)$ & $0.083(0.003)$ & $0.107(0.006)$ & $0.070(0.003)$ \\
\hline \multicolumn{7}{|l|}{ Education } \\
\hline Did not complete high school & $0.155(0.002)$ & $0.244(0.009)$ & $0.148(0.003)$ & $0.137(0.003)$ & $0.115(0.007)$ & $0.152(0.005)$ \\
\hline Completed high school & $0.577(0.003)$ & $0.593(0.011)$ & $0.575(0.003)$ & $0.587(0.005)$ & $0.588(0.010)$ & $0.602(0.007)$ \\
\hline Completed more than high school & $0.268(0.003)$ & $0.163(0.008)$ & $0.277(0.003)$ & $0.276(0.004)$ & $0.297(0.009)$ & $0.245(0.006)$ \\
\hline \multicolumn{7}{|l|}{ Race } \\
\hline Black & $0.125(0.002)$ & $0.332(0.010)$ & $0.108(0.002)$ & $0.107(0.003)$ & $0.134(0.007)$ & $0.091(0.004)$ \\
\hline White & $0.817(0.003)$ & $0.600(0.011)$ & $0.835(0.003)$ & $0.841(0.004)$ & $0.801(0.008)$ & $0.863(0.005)$ \\
\hline Other & $0.058(0.00)$ & $0.067(0.01)$ & $0.057(0.00)$ & $0.052(0.00)$ & $0.066(0.01)$ & $0.046(0.00)$ \\
\hline \multicolumn{7}{|l|}{ Health } \\
\hline Excellent & $0.286(0.003)$ & $0.204(0.009)$ & $0.292(0.003)$ & $0.282(0.004)$ & $0.300(0.010)$ & $0.272(0.006)$ \\
\hline Good & $0.355(0.003)$ & $0.366(0.010)$ & $0.354(0.003)$ & $0.352(0.005)$ & $0.344(0.010)$ & $0.361(0.007)$ \\
\hline Fair & $0.100(0.002)$ & $0.149(0.007)$ & $0.096(0.002)$ & $0.098(0.003)$ & $0.093(0.006)$ & $0.102(0.004)$ \\
\hline Poor & $0.014(0.001)$ & $0.028(0.004)$ & $0.013(0.001)$ & $0.015(0.001)$ & $0.011(0.002)$ & $0.014(0.002)$ \\
\hline \multicolumn{7}{|l|}{ Marital status } \\
\hline Married & $0.570(0.003)$ & $0.000(0.000)$ & $0.617(0.004)$ & $0.695(0.005)$ & $0.000(0.000)$ & $1.000(0.000)$ \\
\hline Widowed & $0.007(0.001)$ & $0.050(0.005)$ & $0.004(0.000)$ & $0.003(0.000)$ & $0.004(0.001)$ & $0.000(0.000)$ \\
\hline Divorced & $0.080(0.002)$ & $0.401(0.010)$ & $0.053(0.001)$ & $0.039(0.002)$ & $0.078(0.005)$ & $0.000(0.000)$ \\
\hline Separated & $0.028(0.001)$ & $0.189(0.008)$ & $0.015(0.001)$ & $0.010(0.001)$ & $0.013(0.002)$ & $0.000(0.000)$ \\
\hline Never married & $0.315(0.003)$ & $0.361(0.010)$ & $0.311(0.003)$ & $0.252(0.005)$ & $0.904(0.005)$ & $0.000(0.000)$ \\
\hline \multicolumn{7}{|l|}{ Employment status } \\
\hline Employed & $0.715(0.003)$ & $0.625(0.010)$ & $0.722(0.003)$ & $0.623(0.005)$ & $0.698(0.010)$ & $0.548(0.007)$ \\
\hline Unemployed & $0.041(0.001)$ & $0.041(0.004)$ & $0.042(0.001)$ & $0.021(0.002)$ & $0.044(0.004)$ & $0.008(0.001)$ \\
\hline Keeping house & $0.147(0.002)$ & $0.254(0.009)$ & $0.138(0.002)$ & $0.264(0.004)$ & $0.048(0.004)$ & $0.403(0.007)$ \\
\hline \multicolumn{7}{|l|}{ Other } \\
\hline Female & $0.536(0.003)$ & $1.000(0.000)$ & $0.498(0.004)$ & $1.000(0.000)$ & $1.000(0.000)$ & $1.000(0.000)$ \\
\hline Children & $1.423(0.010)$ & $2.289(0.031)$ & $1.352(0.011)$ & $1.480(0.016)$ & $0.000(0.000)$ & $2.455(0.018)$ \\
\hline Family income (equivalency scaled in 2008 usd)** & $\$ 32,850$ (\$186) & $\$ 17,090(350.90)$ & $\$ 34,130(196.60)$ & $\$ 33,440$ (272.10) & $\$ 29,290(535.80)$ & $\$ 32,070(334.60)$ \\
\hline Native born & $0.767(0.003)$ & $0.839(0.008)$ & $0.761(0.003)$ & $0.759(0.004)$ & $0.820(0.008)$ & $0.711(0.006)$ \\
\hline Age & $31.60(0.055)$ & $32.55(0.161)$ & $31.52(0.058)$ & $31.65(0.082)$ & $25.51(0.124)$ & $34.14(0.089)$ \\
\hline Observations & 26,005 & 2,799 & 23,206 & 11,433 & 3,021 & 5,837 \\
\hline
\end{tabular}

* where 1 = "not too happy," 2 = "pretty happy," and 3 = "very happy"

** use the OECD equivalency scale where the first adult is equal to 1 , additional adults are equal to 0.5 , and each child (under the age of 18 ) is equivalent to 0.3 .

bolded implies that mean is signiificantly different $(\mathrm{p}<0.05)$ than the mean for single mothers

bold italics implies that means is marginally significantly different $(\mathrm{p}<0.10)$ than the mean for single mothers 
Table II: Coefficient on Single Mother (from Estimating Equation (1))

\begin{tabular}{|c|c|c|c|c|c|c|c|c|c|c|c|c|}
\hline & $\begin{array}{c}\text { Ordered } \\
\text { probit } \\
\text { (happy) } \\
\text { (1) } \\
\end{array}$ & $\begin{array}{c}\text { Ordered } \\
\text { probit } \\
\text { (happy) } \\
\text { (2) }\end{array}$ & $\begin{array}{c}\text { Ordered } \\
\text { probit } \\
\text { (happy) } \\
\text { (3) }\end{array}$ & $\begin{array}{c}\text { Ordered } \\
\text { probit } \\
\text { (happy) } \\
\text { (4) } \\
\end{array}$ & $\begin{array}{c}\begin{array}{c}\text { Probit } \\
\text { (very happy) } \\
\text { (5) }\end{array} \\
\end{array}$ & $\begin{array}{c}\begin{array}{c}\text { Probit } \\
\text { (very happy) } \\
(6)\end{array} \\
\end{array}$ & $\begin{array}{c}\text { Probit } \\
\text { (very happy) } \\
(7)\end{array}$ & $\begin{array}{c}\begin{array}{c}\text { Probit } \\
\text { (very happy) } \\
\text { (8) }\end{array} \\
\end{array}$ & $\begin{array}{c}\begin{array}{c}\text { Probit } \\
\text { (not too happy) } \\
(9)\end{array} \\
\end{array}$ & $\begin{array}{c}\begin{array}{c}\text { Probit } \\
\text { (not too happy) } \\
(10)\end{array} \\
\end{array}$ & $\begin{array}{c}\begin{array}{c}\text { Probit } \\
\text { (not too happy) } \\
(11)\end{array} \\
\end{array}$ & $\begin{array}{c}\text { Probit } \\
\text { (not too happy) } \\
\text { (12) } \\
\end{array}$ \\
\hline \multicolumn{13}{|l|}{ All respondents (Panel A) } \\
\hline \multirow[t]{2}{*}{ Coefficient on Single Mother } & $\begin{array}{c}-0.4880 * * * \\
(0.021)\end{array}$ & $\begin{array}{c}-0.5125 * * * \\
(0.021)\end{array}$ & $\begin{array}{c}-0.0311 \\
(0.028)\end{array}$ & $\begin{array}{c}-0.4391 * * * \\
(0.029)\end{array}$ & $\begin{array}{c}-0.4824 * * * \\
(0.036)\end{array}$ & $\begin{array}{c}-0.5189 * * * \\
(0.036)\end{array}$ & $\begin{array}{c}-0.0183 \\
(0.040)\end{array}$ & $\begin{array}{c}-0.4700 * * * \\
(0.042)\end{array}$ & $\begin{array}{c}0.4935 * * * * \\
(0.025)\end{array}$ & $\begin{array}{c}0.4969 * * * \\
(0.026)\end{array}$ & $\begin{array}{c}0.0335 \\
(0.049)\end{array}$ & $\begin{array}{c}0.3970 \text { *** } \\
(0.044)\end{array}$ \\
\hline & & & & & $\{-0.151\}$ & $\{-0.160\} * * *$ & $\{-0.006\}$ & $\{-0.146\} * * *$ & $\{0.114\} * * *$ & $\{0.111\} * * *$ & $\{0.005\}$ & $\{0.077\} * * *$ \\
\hline Observations & 26,005 & 26,005 & 24,139 & 24,139 & 26,005 & 26,005 & 24,139 & 24,139 & 26,005 & 26,005 & 24,139 & 24,139 \\
\hline \multicolumn{13}{|c|}{ Sample restricted to female respondents (Panel B) } \\
\hline Coefficient on Single Mother & $\begin{array}{c}-0.5807 * * * \\
(0.021)\end{array}$ & $\begin{array}{c}-0.5064 * * * \\
(0.022)\end{array}$ & $\begin{array}{r}-0.0360 \\
(0.037)\end{array}$ & $\begin{array}{c}-0.4209 * * * \\
(0.032)\end{array}$ & $\begin{array}{c}-0.5793 * * * \\
(0.036) \\
\{-0.187\} * * *\end{array}$ & $\begin{array}{c}-0.5114 * * * \\
(0.036) \\
\{-0.168\} * * *\end{array}$ & $\begin{array}{c}-0.0132 \\
(0.055) \\
\{-0.005\}\end{array}$ & $\begin{array}{c}-0.4432 * * * \\
(0.044) \\
\{-0.146\} * * * *\end{array}$ & $\begin{array}{c}0.5822 * * * \\
(0.023) \\
\{0.128\} * * *\end{array}$ & $\begin{array}{c}0.5010 * * * \\
(0.029) \\
\{0.104\} * * *\end{array}$ & $\begin{array}{c}0.0964 \\
(0.071) \\
\{0.015\}\end{array}$ & $\begin{array}{c}0.4002 * * * \\
(0.049) \\
\{0.072\} * * *\end{array}$ \\
\hline Observations & 14,232 & 14,232 & 13,134 & 13,134 & 14,232 & 14,232 & 13,134 & 13,134 & 14,232 & 14,232 & 13,129 & 13,129 \\
\hline \multicolumn{13}{|c|}{ Sample restricted to single female respondents (Panel C) } \\
\hline Coefficient on Single Mother & $\begin{array}{c}-0.3236 * * * \\
(0.030)\end{array}$ & $\begin{array}{c}-0.2267 * * * * \\
(0.032)\end{array}$ & $\begin{array}{l}0.0436 \\
(0.050)\end{array}$ & $\begin{array}{l}0.0436 \\
(0.050)\end{array}$ & $\begin{array}{c}-0.2735 * * * \\
(0.051) \\
\{-0.080\} * * *\end{array}$ & $\begin{array}{c}-0.1799 * * * \\
(0.050) \\
\{-0.053\} * * *\end{array}$ & $\begin{array}{c}0.0828 \\
(0.082) \\
\{0.025\}\end{array}$ & $\begin{array}{c}0.0828 \\
(0.082) \\
\{0.025\}\end{array}$ & $\begin{array}{c}0.3791 * * * \\
(0.027) \\
\{0.093\} * * *\end{array}$ & $\begin{array}{c}0.2784 * * * \\
(0.031) \\
\{0.065\} * * *\end{array}$ & $\begin{array}{c}-0.0045 \\
(0.054) \\
\{-0.001\}\end{array}$ & $\begin{array}{c}-0.0045 \\
\quad(0.054) \\
\{-0.001\}\end{array}$ \\
\hline Observations & 6,422 & 6,422 & 5,837 & 5,837 & 6,422 & 6,422 & 5,818 & 5,818 & 6,422 & 6,422 & 5,832 & 5,832 \\
\hline \multicolumn{13}{|c|}{ Sample restricted to respondents who are mothers (Panel D) } \\
\hline Coefficient on Single Mother & $\begin{array}{c}-0.6734 * * * \\
(0.028)\end{array}$ & $\begin{array}{c}-0.5788 * * * \\
(0.032)\end{array}$ & $\begin{array}{c}-0.4080 * * * \\
(0.036)\end{array}$ & $\begin{array}{c}-0.4080 * * * \\
(0.036)\end{array}$ & $\begin{array}{c}-0.6702 * * * \\
(0.039) \\
\{-0.222\} * * *\end{array}$ & $\begin{array}{c}-0.5808 * * * \\
(0.039) \\
\{-0.195\} * * *\end{array}$ & $\begin{array}{c}-0.4269 * * * \\
(0.045) \\
\{-0.145\} * * *\end{array}$ & $\begin{array}{c}-0.4269 * * * \\
(0.045) \\
\{-0.145\} * * *\end{array}$ & $\begin{array}{c}0.6774 * * * \\
(0.036) \\
\{0.142\} * * *\end{array}$ & $\begin{array}{c}0.5876 * * * \\
(0.049) \\
\{0.116\} * * *\end{array}$ & $\begin{array}{c}0.3909 * * * \\
(0.052) \\
\{0.065\} * * *\end{array}$ & $\begin{array}{l}0.3909 * * * \\
(0.052) \\
\{0.065\} * * *\end{array}$ \\
\hline Observations & 8,636 & 8,636 & 8,082 & 8,082 & 8,636 & 8,636 & 8,082 & 8,082 & 8,636 & 8,636 & 8,080 & 8,080 \\
\hline \multicolumn{13}{|l|}{ Control variables } \\
\hline Exogenous & No & Yes & Yes & Yes & No & Yes & Yes & Yes & No & Yes & Yes & Yes \\
\hline Endogenous except single & No & No & Yes & Yes & No & No & Yes & Yes & No & No & Yes & Yes \\
\hline Single & No & No & Yes & No & No & No & Yes & No & No & No & Yes & No \\
\hline
\end{tabular}

$*$ signifies $\mathrm{p}<0.10$

$* *$ signifies that $\mathrm{p}<0.05$

**** signifies that $\mathrm{p}<0.01$ 
Table III: All Coefficients from Estimating Equation (1)

\begin{tabular}{|c|c|c|c|c|}
\hline & $\begin{array}{l}\text { Ordered probit } \\
\text { (happy) } \\
\text { (1) }\end{array}$ & $\begin{array}{l}\text { Ordered probit } \\
\text { (happy) } \\
\text { (2) }\end{array}$ & $\begin{array}{l}\text { Ordered probit } \\
\text { (happy) } \\
\text { (3) }\end{array}$ & $\begin{array}{l}\text { Ordered probit } \\
\text { (happy) } \\
\text { (4) }\end{array}$ \\
\hline Single mother & $-0.488(0.021) * * *$ & $-0.512(0.021) * * *$ & $-0.439(0.029) * * * *$ & $-0.031(0.028)$ \\
\hline \multicolumn{5}{|l|}{ Exogenous control variables $\wedge$} \\
\hline Male & & $-0.185(0.019) * * *$ & $-0.130(0.030) * * *$ & $-0.129(0.030) * * *$ \\
\hline \multicolumn{5}{|l|}{ Race (reference group is White) } \\
\hline Black & & $-0.401(0.026) * * *$ & $-0.343(0.031) * * *$ & $-0.297(0.031) * * *$ \\
\hline Other nonwhite race & & $-0.162(0.048) * * *$ & $-0.085(0.051) *$ & $-0.066(0.053)$ \\
\hline Non-native born & & $0.006(0.038)$ & $-0.015(0.036)$ & $-0.027(0.038)$ \\
\hline \multicolumn{5}{|l|}{ Endogenous control variables $\wedge$ } \\
\hline Single & & & not included & $-0.455(0.026) * * *$ \\
\hline Mother & & & $0.082(0.037) * *$ & $-0.011(0.034)$ \\
\hline \multicolumn{5}{|c|}{ Educational attainment (reference group is completed high school) } \\
\hline Did not complete high school & & & $-0.049(0.024) * *$ & $-0.057(0.023) * *$ \\
\hline Completed junior college & & & $0.048(0.033)$ & $0.048(0.033)$ \\
\hline Completed bachelor degree & & & $0.096(0.027) * * *$ & $0.090(0.027) * * *$ \\
\hline Completed graduate school & & & $0.100(0.035) * * *$ & $0.077(0.033) * *$ \\
\hline \multicolumn{5}{|l|}{ Self-reported health (reference group is good) } \\
\hline Poor & & & $-0.696(0.085) * * *$ & $-0.683(0.086) * * *$ \\
\hline Fair & & & $-0.429(0.032) * * *$ & $-0.426(0.033) * * *$ \\
\hline Excellent & & & $0.365(0.026) * * *$ & $0.362(0.026)^{* * *}$ \\
\hline Log real family income per equivalent & & & $8.676(5.23) *$ & $9.071(5.201) *$ \\
\hline Square log real family income per equivalent & & & $-1.596(0.86) * *$ & $-1.640(0.847) *$ \\
\hline Unemployed & & & $-0.451(0.050) * * *$ & $-0.402(0.051) * * *$ \\
\hline Observations $\wedge \wedge \wedge$ & 26,005 & 26,005 & 24,139 & 24,139 \\
\hline
\end{tabular}

$\wedge$ An indicator function for each age was included in the ordered probit. There are 28 coefficients on age. Too many to report here.

$\wedge \wedge$ An indicator function for each work status and each number of children was included in the ordered probit. There are 8 coefficients for each variable; too many to report here. One coefficient on work status is reported (unemployed). Also, only the first two terms of the quartic in log real family income per equivalent are reported. Finally, an indicator function for each region was included as well.

$\wedge \wedge$ Weighted number of observations. 1,866 respondents are missing income data. If the quartic in log real income per equivalent is dropped from the ordered probit and all other specifications are the same for columns (3) and (4) the results remain similar.

probit and all other specifications are the same for columns ( 3 and (4) the
$*$ signifies $\mathrm{p}<=0.10$, $* *$ signifies $\mathrm{p}<=0.05$, and $* * *$ signifies $\mathrm{p}<=0.01$ 
Table IV: Trend in Single Mothers’ Happiness (from Estimating Equation (2))

\begin{tabular}{lcccc}
\hline & $\begin{array}{c}\text { Ordered probit } \\
\text { (happy) } \\
(1)\end{array}$ & $\begin{array}{c}\text { Ordered probit } \\
\text { (happy) } \\
(2)\end{array}$ & $\begin{array}{c}\text { Ordered probit } \\
\text { (happy) } \\
(3)\end{array}$ & $\begin{array}{c}\text { Ordered probit } \\
\text { (happy) } \\
(4)\end{array}$ \\
\hline All respondents (Panel A) & & & & \\
& & & & \\
Non-single-mother time trend & $-0.033(0.090)$ & $-0.049(0.123)$ & $-0.176(0.105) *$ & $0.049(0.099)$ \\
Single-mother time trend & $0.447(0.247) *$ & $0.477(0.245) *$ & $0.258(0.212)$ & $0.258(0.217)$ \\
\hline Difference in time trend & $0.480(0.222) * *$ & $0.526(0.245) * *$ & $0.434(0.189) * *$ & $0.209(0.185)$ \\
\hline Observations $\wedge$ & 26,005 & 26,005 & 24,139 & 24,139
\end{tabular}

Sample restricted to female respondent (Panel B)

\begin{tabular}{lcccc} 
Non-single-mother time trend & $-0.193(0.139)$ & $-0.148(0.156)$ & $-0.298(0.146) * *$ & $-0.219(0.141)$ \\
Single-mother time trend & $0.446(0.246) *$ & $0.524(0.255) * *$ & $0.308(0.225)$ & $0.291(0.229)$ \\
\hline Difference in time trend & $0.638(0.257) * *$ & $0.672(0.269) * *$ & $0.606(0.219) * * *$ & $0.510(0.221) * *$ \\
\hline Observations $\wedge$ & 14,232 & 14,232 & 13,134 & 13,134
\end{tabular}

Sample restricted to single female respondents (Panel C)

\begin{tabular}{lllll} 
Non-single-mother time trend & $-0.372(0.274)$ & $-0.651(0.260) * *$ & $-0.795(0.243) * * *$ & $-0.795(0.243) * * *$ \\
Single-mother time trend & $0.458(0.252) *$ & $0.094(0.186)$ & $-0.158(0.206)$ & $-0.158(0.206)$ \\
\hline Difference in time trend & $0.829(0.191) * * *$ & $0.745(0.186) * * *$ & $0.637(0.237) * * *$ & $0.637(0.237) * * *$ \\
\hline Observations^ & 6,422 & 6,422 & 5,837 & 5,837
\end{tabular}

Sample restricted to respondents who are mothers (Panel D)

\begin{tabular}{lcccc} 
Non-single-mother time trend & $0.205(0.237)$ & $0.245(0.215)$ & $-0.081(0.212)$ & $-0.081(0.212)$ \\
Single-mother time trend & $0.446(0.246)$ & $0.523(0.274) *$ & $0.306(0.265)$ & $0.306(0.265)$ \\
\hline Difference in time trend & $0.241(0.360)$ & $0.279(0.364)$ & $0.388(0.324)$ & $0.388(0.324)$ \\
\hline Observation` & 8,636 & 8,636 & 8,082 & 8,082 \\
& & & & \\
& No & Yes & Yes & Yes \\
Exogenous control variables included & No & No & Yes & Yes \\
Endogenous control variables except single included & No & No & No & Yes \\
Single included &
\end{tabular}

$\wedge$ Weighted number of observations. 1,866 respondents are missing income data. If the guartic in log real income per equivalent is dropped fro $*$ signifies $\mathrm{p}<=0.10, * *$ signifies $\mathrm{p}<=0.05$, and $* * *$ signifies $\mathrm{p}<=0.01$ 
Table V: All Coefficients from Estimating Equation (2)

\begin{tabular}{|c|c|c|c|c|}
\hline & $\begin{array}{l}\text { Ordered probit } \\
\text { (happy) } \\
\text { (1) }\end{array}$ & $\begin{array}{l}\text { Ordered probit } \\
\text { (happy) } \\
\text { (2) }\end{array}$ & $\begin{array}{l}\text { Ordered probit } \\
\text { (happy) } \\
\text { (3) }\end{array}$ & $\begin{array}{l}\text { Ordered probit } \\
\text { (happy) } \\
\text { (4) }\end{array}$ \\
\hline Non-single-mother time trend & $-0.033(0.090)$ & $-0.049(0.123)$ & $-0.176(0.105)$ & $0.049(0.099)$ \\
\hline Single mother time trend & $0.447(0.247) *$ & $0.477(0.245) *$ & $0.258(0.212)$ & $0.258(0.217)$ \\
\hline Difference in time trend & $0.480(0.222) * *$ & $0.526(0.245) * *$ & $0.434(0.189) * *$ & $0.209(0.185)$ \\
\hline Single mother & $-0.580(0.048) * * *$ & $-0.614(0.053) * * * *$ & $-0.519(0.050) * * *$ & $-0.071(0.047)$ \\
\hline \multicolumn{5}{|l|}{ Exogenous control variables $\wedge$} \\
\hline Male & & $-0.185(0.019) * * *$ & $-0.130(0.030) * * *$ & $-0.128(0.029) * * * *$ \\
\hline \multicolumn{5}{|l|}{ Race (reference group is White) } \\
\hline Black & & $-0.401(0.026) * * *$ & $-0.341(0.031) * * *$ & $-0.298(0.031) * * *$ \\
\hline Other nonwhite race & & $-0.161(0.051) * * * *$ & $-0.078(0.054)$ & $-0.069(0.056)$ \\
\hline Non-native born & & $0.006(0.037)$ & $-0.013(0.035)$ & $-0.028(0.037)$ \\
\hline \multicolumn{5}{|l|}{ Endogenous control variables $\wedge \wedge$} \\
\hline Single & & & not included & $-0.456(0.025) * * *$ \\
\hline Mother & & & $0.080(0.037) * *$ & $-0.012(0.034)$ \\
\hline \multicolumn{5}{|c|}{ Educational attainment (reference group is completed high school) } \\
\hline Did not complete high school & & & $-0.051(0.024) * *$ & $-0.056(0.023) * *$ \\
\hline Completed junior college & & & $0.051(0.032)$ & $0.046(0.032)$ \\
\hline Completed bachelor degree & & & $0.098(0.026) * * *$ & $0.090(0.027) * * *$ \\
\hline Completed graduate school & & & $0.100(0.035) * * *$ & $0.077(0.033) * *$ \\
\hline \multicolumn{5}{|l|}{ Self-reported health (reference group is good) } \\
\hline Poor & & & $-0.696(0.085) * * *$ & $-0.683(0.085) * * *$ \\
\hline Fair & & & $-0.429(0.032) * * *$ & $-0.426(0.033) * * *$ \\
\hline Excellent & & & $0.364(0.026) * * *$ & $0.363(0.026) * * *$ \\
\hline Log real family income per equivalent & & & $8.529(5.22)$ & $9.241(5.171) *$ \\
\hline Square log real family income per equivalent & & & $-1.568(0.85) \quad *$ & $-1.667(0.843) * *$ \\
\hline Unemployed & & & $-0.451(0.050) * * *$ & $-0.402(0.050) * * *$ \\
\hline Observations $\wedge \wedge \wedge$ & 26,005 & 26,005 & 24,139 & 24,139 \\
\hline
\end{tabular}

$\wedge$ An indicator function for each age was included in the ordered probit. There are 28 coefficients on age. Too many to report here.

$\wedge \wedge$ An indicator function for each work status and each number of children was included in the ordered probit. There are 8 coefficients for each variable; too many to report here. One coefficient on work status is reported (unemployed). Also, only the first two terms of the

quartic in log real family income per equivalent are reported. Finally, an indicator ftnction for each region was included as well.

$\wedge \wedge$ Weighted number of observations. 1,866 respondents are missing income data. If the quartic in log real income per equivalent is
dropped from the ordered probit and all other specifications are the same for columns (3) and (4) the results remain similar.

$*$ signifies $\mathrm{p}<=0.10, * *$ signifies $\mathrm{p}<=0.05$, and $* * *$ signifies $\mathrm{p}<=0.01$ 
Table VI: Time Trends between 1972 and 1989, and between 1990 and 2008

\begin{tabular}{|c|c|c|c|c|c|c|c|c|}
\hline & \multicolumn{4}{|c|}{ All respondents } & \multicolumn{4}{|c|}{ Sample restricted to female respondents } \\
\hline & $\begin{array}{l}\text { Ordered probit } \\
\text { (happy) } \\
\text { (1) }\end{array}$ & $\begin{array}{l}\text { Ordered probit } \\
\text { (happy) } \\
\text { (2) }\end{array}$ & $\begin{array}{l}\text { Ordered probit } \\
\text { (happy) } \\
\text { (3) }\end{array}$ & $\begin{array}{l}\text { Ordered probit } \\
\text { (happy) } \\
\text { (4) }\end{array}$ & $\begin{array}{l}\text { Ordered probit } \\
\text { (happy) } \\
\text { (5) }\end{array}$ & $\begin{array}{l}\text { Ordered probit } \\
\text { (happy) } \\
\text { (6) }\end{array}$ & $\begin{array}{l}\text { Ordered probit } \\
\text { (happy) } \\
\text { (7) }\end{array}$ & $\begin{array}{l}\text { Ordered probit } \\
\text { (happy) } \\
\text { (8) }\end{array}$ \\
\hline \multicolumn{9}{|l|}{ All respondents (Panel A) } \\
\hline Non-single-mother time trend & $-0.033(0.090)$ & $-0.049(0.123)$ & $-0.176(0.105) *$ & $0.049(0.099)$ & $-0.193(0.139)$ & $-0.148(0.156)$ & $-0.298(0.146) * *$ & $-0.219(0.141)$ \\
\hline Single-mother time trend & $0.447(0.247) *$ & $0.477(0.245) *$ & $0.258(0.212)$ & $0.258(0.217)$ & $0.446(0.246) *$ & $0.524(0.255) * *$ & $0.308(0.225)$ & $0.291(0.229)$ \\
\hline Difference in time trend & $0.480(0.222) * *$ & $0.526(0.245) * *$ & $0.434(0.189) * *$ & $0.209(0.185)$ & $0.638(0.257) * *$ & $0.672(0.269) * *$ & $0.606(0.219) * * *$ & $0.510(0.221) * *$ \\
\hline
\end{tabular}

Trend between 1972 and 1989 GSS (Panel B)

\begin{tabular}{|c|c|c|c|c|c|c|c|c|}
\hline Non-single-mother time trend & $0.392(0.238) *$ & $0.354(0.375)$ & $0.083(0.383)$ & $0.346(0.381)$ & $-0.020(0.332)$ & $0.070(0.423)$ & $-0.094(0.445)$ & $0.031(0.424)$ \\
\hline Single-mother time trend & $1.742(0.520) * * *$ & $1.677(0.591) * * *$ & $0.465(0.571)$ & $0.527(0.574)$ & $1.736(0.518) * * *$ & $1.804(0.615) * * *$ & $0.736(0.617)$ & $0.742(0.627)$ \\
\hline Difference in time trend & $1.349(0.616) * *$ & $1.323(0.653) * *$ & $0.382(0.583)$ & $0.181(0.583)$ & $1.756(0.685) * * *$ & $1.734(0.688) * *$ & $0.830(0.655)$ & $0.712(0.664)$ \\
\hline
\end{tabular}

Trend between 1990 and 2008 GSS (Panel C)

\begin{tabular}{|c|c|c|c|c|c|c|c|c|}
\hline Non-single-mother time trend & $0.040(0.097)$ & $0.084(0.161)$ & $-0.095(0.156)$ & $0.142(0.151)$ & $-0.163(0.153)$ & $-0.061(0.184)$ & $-0.230(0.192)$ & $-0.137(0.184)$ \\
\hline Single-mother time trend & $-0.106(0.532)$ & $-0.001(0.584)$ & $0.138(0.556)$ & $0.115(0.543)$ & $-0.105(0.530)$ & $-0.033(0.587)$ & $0.059(0.540)$ & $0.032(0.535)$ \\
\hline Difference in time trend & $-0.146(0.530)$ & $-0.085(0.569)$ & $0.233(0.533)$ & $-0.027(0.516)$ & $0.058(0.542)$ & $0.028(0.574)$ & $0.288(0.543)$ & $0.168(0.531)$ \\
\hline Observations^ & 26,005 & 26,005 & 24,139 & 24,139 & 14,232 & 14,232 & 13,134 & 13,134 \\
\hline Exogenous control variables included & No & Yes & Yes & Yes & No & Yes & Yes & Yes \\
\hline Endogenous control variables except single included & No & No & Yes & Yes & No & No & Yes & Yes \\
\hline Single included & No & No & No & Yes & No & No & No & Yes \\
\hline
\end{tabular}

$\wedge$ Weighted number of observations. 1,866 respondents are missing income data. If the quartic in log real income per equivalent is dropped from the ordered probit and all other specifications are the same for columns (3) and (4) the * signifies $\mathrm{p}<=0.10,{ }^{* *}$ signifies $\mathrm{p}<=0.05$, and ${ }^{* * *}$ signifies $\mathrm{p}<=0.01$ 
Table VII: Trend in Single Mothers’ Distribution of Happiness (from Estimating Equation (2))

\begin{tabular}{|c|c|c|c|c|c|c|c|c|}
\hline & $\begin{array}{l}\text { Probit } \\
\text { (very happy) } \\
\text { (1) }\end{array}$ & $\begin{array}{l}\text { Probit } \\
\text { (very happy) } \\
\text { (2) }\end{array}$ & $\begin{array}{c}\text { Probit } \\
\text { (very happy) } \\
\text { (3) }\end{array}$ & $\begin{array}{l}\text { Probit } \\
\text { (very happy) } \\
\text { (4) }\end{array}$ & $\begin{array}{c}\text { Probit } \\
\text { (not too happy) } \\
\text { (5) }\end{array}$ & $\begin{array}{c}\text { Probit } \\
\text { (not too happy) } \\
\text { (6) }\end{array}$ & $\begin{array}{c}\text { Probit } \\
\text { (not too happy) } \\
\text { (7) }\end{array}$ & $\begin{array}{c}\text { Probit } \\
\text { (not too happy) } \\
\text { (8) }\end{array}$ \\
\hline \multicolumn{9}{|l|}{ All respondents (Panel A) } \\
\hline Non-single-mother time trend & $-0.129(0.096)$ & $-0.015(0.107)$ & $-0.119(0.100)$ & $0.105(0.093)$ & $-0.167(0.191)$ & $0.105(0.220)$ & $0.295(0.181)$ & $0.070(0.180)$ \\
\hline Single-mother time trend & $0.133(0.232)$ & $0.233(0.262)$ & $0.095(0.273)$ & $0.094(0.274)$ & $-0.711(0.358) * *$ & $-0.554(0.337) *$ & $-0.210(0.310)$ & $-0.208(0.312)$ \\
\hline Difference in time trend & $0.262(0.275)$ & $0.248(0.285)$ & $0.214(0.271)$ & $-0.010(0.263)$ & $-0.544(0.275) * *$ & $-0.659(0.288) * *$ & $-0.505(0.228) * *$ & $-0.278(0.227)$ \\
\hline Observations^ & 26,005 & 26,005 & 24,139 & 24,139 & 26,005 & 26,005 & 24,133 & 24,139 \\
\hline
\end{tabular}

Sample restricted to female respondent (Panel B)

\begin{tabular}{|c|c|c|c|c|c|c|c|c|c|}
\hline Non-single-mother time trend & $-0.328(0.156) * *$ & $-0.146(0.159)$ & $-0.236(0.157)$ & $-0.161(0.151)$ & $-0.138(0.212)$ & $0.110(0.275)$ & $0.380(0.234)$ & $0.309(0.235)$ & \\
\hline Single-mother time trend & $0.133(0.232)$ & $0.279(0.281)$ & $0.131(0.297)$ & $0.113(0.298)$ & $-0.711(0.358) * *$ & $-0.583(0.326) *$ & $-0.248(0.294)$ & $-0.238(0.295)$ & \\
\hline Difference in time trend & $0.461(0.309)$ & $0.425(0.311)$ & $0.368(0.306)$ & $0.274(0.302)$ & $-0.574(0.249) * *$ & $-0.693(0.271) * * *$ & $-0.628(0.219) * * *$ & $-0.547(0.218)$ & ** \\
\hline
\end{tabular}

Sample restricted to single female respondents (Panel C)

\begin{tabular}{lccccccccc} 
Non-single-mother time trend & $-0.556(0.291) *$ & $-0.649(0.325) * *$ & $-0.759(0.310)$ & $-0.759(0.310) * *$ & $0.098(0.377)$ & $0.604(0.344) *$ & $0.834(0.318) * * *$ & $0.834(0.318)$ & $* * *$ \\
Single-mother time trend & $0.133(0.232)$ & $-0.045(0.219)$ & $-0.183(0.259)$ & $-0.183(0.259)$ & $-0.711(0.358) * *$ & $-0.080(0.297)$ & $0.264(0.327)$ & $0.264(0.327)$ \\
\hline Difference in time trend & $0.689(0.345) * *$ & $0.603(0.361) *$ & $0.576(0.379)$ & $0.576(0.379)$ & $-0.810(0.224) * * *$ & $-0.684(0.203) * * *$ & $-0.570(0.270) * *$ & $-0.570(0.270)$ & $* * *$ \\
\hline Observations & 6,422 & 6,422 & 5,818 & 5,818 & 6,422 & 6,422 & 5,832 & 5,832
\end{tabular}

Sample restricted to respondents who are mothers (Panel D)

\begin{tabular}{lccccccccc} 
Non-single-mother time trend & $-0.027(0.262)$ & $0.165(0.240)$ & $-0.063(0.221)$ & $-0.063(0.221)$ & $-0.890(0.264) * * *$ & $-0.627(0.348) *$ & $-0.031(0.302)$ & $-0.031(0.302)$ \\
Single-mother time trend & $0.133(0.232)$ & $0.247(0.319)$ & $0.100(0.335)$ & $0.100(0.335)$ & $-0.711(0.358) * *$ & $-0.643(0.325) * *$ & $-0.292(0.294)$ & $-0.292(0.294)$ \\
\hline Difference in time trend & $0.160(0.380)$ & $0.083(0.361)$ & $0.163(0.37)$ & $0.163(0.370)$ & $0.179(0.429)$ & $-0.015(0.450)$ & $-0.262(0.408)$ & $-0.262(0.408)$ \\
\hline Observations & 8,636 & 8,636 & 8,082 & 8,082 & 8,636 & 8,636 & 8,080 & 8,080
\end{tabular}

\begin{tabular}{|c|c|c|c|c|c|c|c|c|}
\hline Exogenous control variables included & No & Yes & Yes & Yes & No & Yes & Yes & Yes \\
\hline Endogenous control variables except single included & No & No & Yes & Yes & No & No & Yes & Yes \\
\hline Single included & No & No & No & Yes & No & No & No & Yes \\
\hline
\end{tabular}

$\wedge$ Weighted number of observations. 1,866 respondents are missing income data. If the quartic in log real income per equivalent is dropped from the ordered probit and all other speciifcations are the same for columns (3) and (4) the results remain similiars $\mathrm{p}<=0.10, * *$ signifies $\mathrm{p}<=0.05$, and $* * *$ signifies $\mathrm{p}<=0.01$ 
Table VIII: Time Trends by Educational Attainment

\begin{tabular}{|c|c|c|c|c|c|c|c|c|}
\hline & \multicolumn{4}{|c|}{ All respondents } & \multicolumn{4}{|c|}{ Sample restricted to female respondents } \\
\hline & $\begin{array}{l}\text { Ordered probit } \\
\text { (happy) } \\
\text { (1) }\end{array}$ & $\begin{array}{l}\text { Ordered probit } \\
\text { (happy) } \\
\text { (2) }\end{array}$ & $\begin{array}{l}\text { Ordered probit } \\
\text { (happy) } \\
\text { (3) }\end{array}$ & $\begin{array}{l}\text { Ordered probit } \\
\text { (happy) } \\
\text { (4) }\end{array}$ & $\begin{array}{l}\text { Ordered probit } \\
\text { (happy) } \\
\text { (5) }\end{array}$ & $\begin{array}{l}\text { Ordered probit } \\
\text { (happy) } \\
\text { (6) }\end{array}$ & $\begin{array}{l}\text { Ordered probit } \\
\text { (happy) } \\
\text { (7) }\end{array}$ & $\begin{array}{l}\text { Ordered probit } \\
\text { (happy) } \\
\text { (8) }\end{array}$ \\
\hline \multicolumn{9}{|l|}{ All respondents (Panel A) } \\
\hline Non-single-mother time trend & $-0.033(0.090)$ & $-0.049(0.123)$ & $-0.176(0.105) *$ & $0.049(0.099)$ & $-0.193(0.139)$ & $-0.148(0.156)$ & $-0.298(0.146) * *$ & $-0.219(0.141)$ \\
\hline Single-mother time trend & $0.447(0.247) *$ & $0.477(0.245) *$ & $0.258(0.212)$ & $0.258(0.217)$ & $0.446(0.246) *$ & $0.524(0.255) * *$ & $0.308(0.225)$ & $0.291(0.229)$ \\
\hline Difference in time trend & $0.480(0.222) * *$ & $0.526(0.245) * *$ & $0.434(0.189) * *$ & $0.209(0.185)$ & $0.638(0.257) * *$ & $0.672(0.269) * *$ & $0.606(0.219) * * *$ & $0.510(0.221) * *$ \\
\hline
\end{tabular}

Trend for respondents who did not complete high school (Panel B)

\begin{tabular}{lccccccccc} 
Non--single-mother time trend & $-1.221(0.169) * * *$ & $-1.062(0.186) * * *$ & $-0.248(0.256)$ & $0.053(0.249)$ & $-1.553(0.224) * * *$ & $-1.354(0.232) * * *$ & $-0.447(0.329)$ & $-0.350(0.326)$ \\
Single-mother time trend & $0.858(0.761)$ & $0.898(0.756)$ & $0.561(0.642)$ & $0.525(0.643)$ & $0.856(0.758)$ & $0.958(0.743)$ & $0.642(0.624)$ & $0.601(0.622)$ \\
\hline Difference in time trend & $2.079(0.762) * * *$ & $1.959(0.75) * *$ & $0.808(0.642)$ & $0.472(0.653)$ & $2.408(0.743) * * *$ & $2.312(0.74) * * *$ & $1.088(0.597) *$ & $0.950(0.604)$ \\
\hline
\end{tabular}

Trend for respondents who completed high school (Panel C)

\begin{tabular}{lllllllll} 
Non-single-mother time trend & $-0.302(0.094) * * *$ & $-0.308(0.114) * * *$ & $-0.240(0.111) * *$ & $0.010(0.110)$ & $-0.466(0.122) * * *$ & $-0.417(0.156) * * *$ & $-0.353(0.154) * *$ & $-0.274(0.156) *$ \\
Single-mother time trend & $-0.046(0.256)$ & $0.050(0.254)$ & $0.143(0.227)$ & $0.110(0.228)$ & $-0.046(0.25)$ & $0.093(0.263)$ & $0.155(0.226)$ & $0.117(0.229)$ \\
\hline Difference in time trend & $0.256(0.264)$ & $0.359(0.282)$ & $0.382(0.202) *$ & $0.100(0.201)$ & $0.420(0.29)$ & $0.511(0.306) *$ & $0.508(0.222) * *$ & $0.391(0.225) *$ \\
\hline
\end{tabular}

Trend for respondents who completed more than high school (Panel D)

\begin{tabular}{|c|c|c|c|c|c|c|c|c|}
\hline Non-single-mother time trend & $0.619(0.120) * * *$ & $0.458(0.151) * * *$ & $-0.008(0.176)$ & $0.147(0.176)$ & $0.365(0.150) * *$ & $0.301(0.170) *$ & $-0.114(0.292)$ & $-0.035(0.287)$ \\
\hline Single-mother time trend & $0.162(0.562)$ & $0.011(0.546)$ & $-0.150(0.596)$ & $-0.092(0.613)$ & $0.162(0.560)$ & $0.053(0.554)$ & $0.028(0.611)$ & $0.069(0.624)$ \\
\hline Difference in time trend & $-0.457(0.626)$ & $-0.447(0.609)$ & $-0.142(0.610)$ & $-0.239(0.616)$ & $-0.203(0.616)$ & $-0.249(0.595)$ & $0.142(0.639)$ & $0.105(0.637)$ \\
\hline Observations^ & 26,005 & 26,005 & 24,139 & 24,139 & 14,232 & 14,232 & 13,134 & 13,134 \\
\hline Exogenous control variables included & No & Yes & Yes & Yes & No & Yes & Yes & Yes \\
\hline Endogenous control variables except single included & No & No & Yes & Yes & No & No & Yes & Yes \\
\hline Single included & No & No & No & Yes & No & No & No & Yes \\
\hline
\end{tabular}

$\wedge$ Weighted number of observations. 1,866 respondents are missing income data. If the quartic in log real income per equivalent is dropped from the ordered probit and all other speciifations are the same for columns (3) and (4) the results

* 
Table IX: Time Trends by Employment Status

\begin{tabular}{|c|c|c|c|c|c|c|c|c|}
\hline & \multicolumn{4}{|c|}{ All respondents } & \multicolumn{4}{|c|}{ Sample restricted to female respondents } \\
\hline & $\begin{array}{l}\text { Ordered probit } \\
\text { (happy) } \\
\text { (1) }\end{array}$ & $\begin{array}{l}\text { Ordered probit } \\
\text { (happy) } \\
\text { (2) }\end{array}$ & $\begin{array}{l}\text { Ordered probit } \\
\text { (happy) } \\
\text { (3) }\end{array}$ & $\begin{array}{l}\text { Ordered probit } \\
\text { (happy) } \\
\text { (4) }\end{array}$ & $\begin{array}{l}\text { Ordered probit } \\
\text { (happy) } \\
\text { (5) }\end{array}$ & $\begin{array}{l}\text { Ordered probit } \\
\text { (happy) } \\
\text { (6) }\end{array}$ & $\begin{array}{l}\text { Ordered probit } \\
\text { (happy) } \\
\text { (7) }\end{array}$ & $\begin{array}{l}\text { Ordered probit } \\
\text { (happy) } \\
\text { (8) }\end{array}$ \\
\hline \multicolumn{9}{|l|}{ All respondents (Panel A) } \\
\hline Non-single-mother time trend & $-0.033(0.090)$ & $-0.049(0.123)$ & $-0.176(0.105) *$ & $0.049(0.099)$ & $-0.193(0.139)$ & $-0.148(0.156)$ & $-0.298(0.146) * *$ & $-0.219(0.141)$ \\
\hline Single-mother time trend & $0.447(0.247) *$ & $0.477(0.245) *$ & $0.258(0.212)$ & $0.258(0.217)$ & $0.446(0.246) *$ & $0.524(0.255) * *$ & $0.308(0.225)$ & $0.291(0.229)$ \\
\hline Difference in time trend & $0.480(0.222) * *$ & $0.526(0.245) * *$ & $0.434(0.189) * *$ & $0.209(0.185)$ & $0.638(0.257) * *$ & $0.672(0.269) * *$ & $0.606(0.219) * * *$ & $0.510(0.221) * *$ \\
\hline
\end{tabular}

Trend for respondents who are employed (Panel B)

\begin{tabular}{|c|c|c|c|c|c|c|c|c|}
\hline Non-single-mother time trend & $0.058(0.098)$ & $0.064(0.133)$ & $-0.164(0.121)$ & $0.086(0.112)$ & $-0.226(0.155)$ & $-0.188(0.172)$ & $-0.292(0.200)$ & $-0.197(0.193)$ \\
\hline Single-mother time trend & $0.076(0.267)$ & $0.205(0.271)$ & $0.041(0.297)$ & $0.036(0.297)$ & $0.076(0.266)$ & $0.245(0.271)$ & $0.119(0.287)$ & $0.114(0.289)$ \\
\hline Difference in time trend & $0.018(0.259)$ & $0.141(0.277)$ & $0.205(0.288)$ & $-0.049(0.279)$ & $0.302(0.279)$ & $0.433(0.298)$ & $0.410(0.298)$ & $0.311(0.298)$ \\
\hline
\end{tabular}

Trend for respondents who are not employed (Panel C)

\begin{tabular}{|c|c|c|c|c|c|c|c|c|}
\hline Non-single-mother time trend & $-0.330(0.102) * * *$ & $-0.385(0.122) * * *$ & $-0.190(0.162)$ & $-0.026(0.160)$ & $-0.115(0.141)$ & $-0.024(0.147)$ & $-0.265(0.209)$ & $-0.210(0.200)$ \\
\hline Single-mother time trend & $0.725(0.287) * * *$ & $0.691(0.273) * *$ & $0.514(0.248) * *$ & $0.480(0.261) *$ & $0.723(0.286) * *$ & $0.747(0.298) * *$ & $0.475(0.291)$ & $0.416(0.299)$ \\
\hline Difference in time trend & $1.055(0.270) * * *$ & $1.075(0.289) * * *$ & $0.704(0.314) * *$ & $0.506(0.319)$ & $0.838(0.297) * * *$ & $0.772(0.284) * * *$ & $0.740(0.317) * *$ & $0.625(0.319) * *$ \\
\hline Observations^ & 26,005 & 26,005 & 24,139 & 24,139 & 14,232 & 14,232 & 13,134 & 13,134 \\
\hline Exogenous control variables included & No & Yes & Yes & Yes & No & Yes & Yes & Yes \\
\hline Endogenous control variables except single included & No & No & Yes & Yes & No & No & Yes & Yes \\
\hline Single included & No & No & No & Yes & No & No & No & Yes \\
\hline
\end{tabular}

$\wedge$ Weighted number of observations. 1,866 respondents are missing income data. If the quartic in log real income per equivalent is dropped from the ordered probit and all other specifications are the same for columns (3) and (4) the

$*$ signifies $\mathrm{p}<=0.10, * *$ signifies $\mathrm{p}<=0.05$, and $* * *$ signifies $\mathrm{p}<=0.01$ 
Table X: Time Trends by Age of Youngest

\begin{tabular}{|c|c|c|c|c|c|c|c|c|}
\hline & $\begin{array}{l}\text { Ordered probit } \\
\text { (happy) } \\
\text { (1) }\end{array}$ & $\begin{array}{l}\text { Ordered probit } \\
\text { (happy) } \\
\text { (2) }\end{array}$ & $\begin{array}{l}\text { Ordered probit } \\
\text { (happy) } \\
\text { (3) }\end{array}$ & $\begin{array}{l}\text { Ordered probit } \\
\text { (happy) } \\
\text { (4) }\end{array}$ & $\begin{array}{l}\text { Ordered probit } \\
\text { (happy) } \\
\text { (5) }\end{array}$ & $\begin{array}{l}\text { Ordered probit } \\
\text { (happy) } \\
\text { (6) }\end{array}$ & $\begin{array}{l}\text { Ordered probit } \\
\text { (happy) } \\
\text { (7) }\end{array}$ & $\begin{array}{l}\text { Ordered probit } \\
\text { (happy) } \\
\text { (8) }\end{array}$ \\
\hline \multicolumn{9}{|l|}{ All respondents (Panel A) } \\
\hline Non-single-mother time trend & $-0.033(0.090)$ & $-0.049(0.123)$ & $-0.176(0.105) *$ & $0.049(0.099)$ & $-0.193(0.139)$ & $-0.148(0.156)$ & $-0.298(0.146) * *$ & $-0.219(0.141)$ \\
\hline Single-mother time trend & $0.447(0.247) *$ & $0.477(0.245) *$ & $0.258(0.212)$ & $0.258(0.217)$ & $0.446(0.246) *$ & $0.524(0.255) * *$ & $0.308(0.225)$ & $0.291(0.229)$ \\
\hline Difference in time trend & $0.480(0.222) * *$ & $0.526(0.245) * *$ & $0.434(0.189) * *$ & $0.209(0.185)$ & $0.638(0.257) * *$ & $0.672(0.269) * *$ & $0.606(0.219) * * *$ & $0.510(0.221) * *$ \\
\hline
\end{tabular}

Trends for respondents whose youngest child is between 0-6 years old (Panel B)

\begin{tabular}{|c|c|c|c|c|c|c|c|c|}
\hline Non-single-mother time trend & $0.736(0.135)^{* * * *}$ & $0.653(0.130) * * *$ & $0.364(0.178) * *$ & $0.076(0.160)$ & $0.627(0.130) * * *$ & $0.611(0.125) * * *$ & $-0.101(0.216)$ & $-0.103(0.214)$ \\
\hline Single-mother time trend & $0.853(0.302) * * *$ & $0.969(0.282) * * *$ & $0.689(0.280) * *$ & $0.577(0.284) * *$ & $0.850(0.300) * * *$ & $1.033(0.288) * * *$ & $0.714(0.279)$ & $0.680(0.283) * *$ \\
\hline Difference in time trend & $0.117(0.301)$ & $0.316(0.276)$ & $0.325(0.289)$ & $0.501(0.277) *$ & $0.223(0.326)$ & $0.422(0.311)$ & $0.814(0.333) * *$ & $0.783(0.339) * *$ \\
\hline
\end{tabular}

Trend for respondents whose youngest child is between 7 and 12 years old (Panel C)

\begin{tabular}{|c|c|c|c|c|c|c|c|c|}
\hline Non-single-mother time trend & $0.620(0.124) * * *$ & $0.544(0.132) * * *$ & $0.392(0.160) * *$ & $0.207(0.145)$ & $0.562(0.250) * *$ & $0.583(0.261) * *$ & $0.001(0.298)$ & $0.051(0.302)$ \\
\hline Single-mother time trend & $0.218(0.335)$ & $0.227(0.384)$ & $0.288(0.342)$ & $0.211(0.331)$ & $0.217(0.334)$ & $0.342(0.398)$ & $0.311(0.334)$ & $0.301(0.332)$ \\
\hline Difference in time trend & $-0.402(0.385)$ & $-0.317(0.413)$ & $-0.104(0.364)$ & $0.004(0.369)$ & $-0.345(0.458)$ & $-0.242(0.489)$ & $0.311(0.471)$ & $0.251(0.473)$ \\
\hline
\end{tabular}

Trend for respondents whose youngest child is between 13 and 17 years old (Panel D)

\begin{tabular}{|c|c|c|c|c|c|c|c|c|}
\hline Non-single-mother time trend & $0.245(0.151)$ & $0.388(0.158) * *$ & $0.264(0.177)$ & $0.182(0.166)$ & $0.275(0.181)$ & $0.469(0.214) * *$ & $-0.024(0.214)$ & $0.122(0.212)$ \\
\hline Single-mother time trend & $-0.391(0.918)$ & $-0.001(0.941)$ & $-0.188(0.711)$ & $-0.333(0.671)$ & $-0.390(0.916)$ & $0.045(0.945)$ & $-0.315(0.707)$ & $-0.362(0.694)$ \\
\hline Difference in time trend & $-0.636(0.932)$ & $-0.390(0.962)$ & $-0.452(0.746)$ & $-0.514(0.726)$ & $-0.665(0.922)$ & $-0.425(0.951)$ & $-0.291(0.716)$ & $-0.484(0.711)$ \\
\hline Observations^ ${ }^{\wedge}$ & 25,814 & 25,814 & 23,971 & 23,971 & 14,124 & 14,124 & 13,039 & 13,039 \\
\hline Exogenous control variables included & No & Yes & Yes & Yes & No & Yes & Yes & Yes \\
\hline Endogenous control variables except single included & No & No & Yes & Yes & No & No & Yes & Yes \\
\hline Single included & No & No & No & Yes & No & No & No & Yes \\
\hline
\end{tabular}

${ }^{\wedge}$ Weighted number of observations. 1,866 respondents are missing income data. If the quartic in log real income per equivalent is dropped from the ordered probit and all other specifications are the same for columns (3) and (4) the results remain $*$ signifies $\mathrm{p}<=0.10,{ }^{* *}$ signifies $\mathrm{p}<=0.05$, and ${ }^{* * *}$ signifies $\mathrm{p}<=0.01$ 
Table XI: Time Trends by Presence of Other Adult (Age 18+) in the household

\begin{tabular}{|c|c|c|c|c|c|c|c|c|}
\hline & \multicolumn{4}{|c|}{ All respondents } & \multicolumn{4}{|c|}{ Sample restricted to female respondents } \\
\hline & $\begin{array}{l}\text { Ordered probit } \\
\text { (happy) } \\
\text { (1) }\end{array}$ & $\begin{array}{l}\text { Ordered probit } \\
\text { (happy) } \\
\text { (2) }\end{array}$ & $\begin{array}{l}\text { Ordered probit } \\
\text { (happy) } \\
\text { (3) }\end{array}$ & $\begin{array}{l}\text { Ordered probit } \\
\text { (happy) } \\
\text { (4) }\end{array}$ & $\begin{array}{l}\text { Ordered probit } \\
\text { (happy) } \\
\text { (5) }\end{array}$ & $\begin{array}{l}\text { Ordered probit } \\
\text { (happy) } \\
\text { (6) }\end{array}$ & $\begin{array}{l}\text { Ordered probit } \\
\text { (happy) } \\
\text { (7) }\end{array}$ & $\begin{array}{l}\text { Ordered probit } \\
\text { (happy) } \\
\text { (8) }\end{array}$ \\
\hline \multicolumn{9}{|l|}{ All respondents (Panel A) } \\
\hline Non-single-mother time trend & $-0.033(0.090)$ & $-0.049(0.123)$ & $-0.176(0.105) *$ & $0.049(0.099)$ & $-0.193(0.139)$ & $-0.148(0.156)$ & $-0.298(0.146) * *$ & $-0.219(0.141)$ \\
\hline Single-mother time trend & $0.447(0.247) *$ & $0.477(0.245) *$ & $0.258(0.212)$ & $0.258(0.217)$ & $0.446(0.246) *$ & $0.524(0.255) * *$ & $0.308(0.225)$ & $0.291(0.229)$ \\
\hline Difference in time trend & $0.480(0.222) * *$ & $0.526(0.245) * *$ & $0.434(0.189) * *$ & $0.209(0.185)$ & $0.638(0.257) * *$ & $0.672(0.269) * *$ & $0.606(0.219) * * *$ & $0.510(0.221) * *$ \\
\hline
\end{tabular}

Trend for respondents who do not live with any other adults (Panel B)

\begin{tabular}{|c|c|c|c|c|c|c|c|c|}
\hline Non-single-mother time trend & $-1.319(0.132) * * *$ & $-1.268(0.172) * * *$ & $-1.424(0.162)$ & $-0.541(0.136) * * \mathrm{~s}$ & $-1.556(0.196) * * *$ & $-1.418(0.215) * * *$ & $-1.459(0.196) * * *$ & $-0.827(0.207) * * *$ \\
\hline Single-mother time trend & $0.301(0.232)$ & $0.547(0.256) * *$ & $0.297(0.262)$ & $0.270(0.267)$ & $0.300(0.232)$ & $0.581(0.259) * *$ & $0.325(0.272)$ & $0.298(0.274)$ \\
\hline Difference in time trend & $1.620(0.216) * * *$ & $1.815(0.219) * * *$ & $1.721(0.217)^{* * *}$ & $0.812(0.236) * * *$ & $1.856(0.251)^{* * *}$ & $2.000(0.246) * * *$ & $1.784(0.244) * * *$ & $1.125(0.258) * * *$ \\
\hline
\end{tabular}

Trend for respondents who live with at least one other adult (Panel C)

\begin{tabular}{|c|c|c|c|c|c|c|c|c|}
\hline Non-single-mother time trend & $0.170(0.089) *$ & $0.158(0.120)$ & $0.010(0.105)$ & $0.113(0.100)$ & $-0.007(0.132)$ & $0.043(0.141)$ & $-0.160(0.137)$ & $-0.157(0.136)$ \\
\hline Single-mother time trend & $0.594(0.508)$ & $0.440(0.525)$ & $0.236(0.459)$ & $0.247(0.457)$ & $0.592(0.506)$ & $0.499(0.529)$ & $0.309(0.472)$ & $0.290(0.472)$ \\
\hline Difference in time trend & $0.423(0.480)$ & $0.281(0.529)$ & $0.226(0.455)$ & $0.134(0.450)$ & $0.599(0.506)$ & $0.456(0.547)$ & $0.469(0.494)$ & $0.447(0.496)$ \\
\hline Observations^ $^{\wedge}$ & 26,005 & 26,005 & 24,139 & 24,139 & 14,232 & 14,232 & 13,134 & 13,134 \\
\hline Exogenous control variables included & No & Yes & Yes & Yes & No & Yes & Yes & Yes \\
\hline Endogenous control variables except single included & No & No & Yes & Yes & No & No & Yes & Yes \\
\hline Single included & No & No & No & Yes & No & No & No & Yes \\
\hline
\end{tabular}

Weighted number of observations. 1,866 respondents are missing income data. If the quartic in log real income per equivalent is dropped from the ordered probit and all other specifications are the same for columns (3) and (4) the results remain ${ }^{*}$ signifies $\mathrm{p}<=0.10, * *$ signifies $\mathrm{p}<=0.05$, and ${ }^{* * *}$ signifies $\mathrm{p}<=0.01$ 
Table XII: Time Trends by Marital Status

\begin{tabular}{|c|c|c|c|c|c|c|c|c|c|c|c|c|}
\hline & \multicolumn{4}{|c|}{ All respondents } & \multicolumn{4}{|c|}{ Sample restricted to female respondents } & \multicolumn{4}{|c|}{ Sample restricted to single female respondents } \\
\hline & $\begin{array}{l}\text { Ordered probit } \\
\text { (happy) } \\
\text { (1) }\end{array}$ & $\begin{array}{l}\text { Ordered probit } \\
\text { (happy) } \\
\text { (2) }\end{array}$ & $\begin{array}{l}\text { Ordered probit } \\
\text { (happy) } \\
\text { (3) }\end{array}$ & $\begin{array}{l}\text { Ordered probit } \\
\text { (happy) } \\
\text { (4) }\end{array}$ & $\begin{array}{l}\text { Ordered probit } \\
\text { (happy) } \\
\text { (5) }\end{array}$ & $\begin{array}{l}\text { Ordered probit } \\
\text { (happy) } \\
\text { (6) }\end{array}$ & $\begin{array}{l}\text { Ordered probit } \\
\text { (happy) } \\
\text { (7) }\end{array}$ & $\begin{array}{l}\text { Ordered probit } \\
\text { (happy) } \\
\text { (8) }\end{array}$ & $\begin{array}{l}\text { Ordered probit } \\
\text { (happy) } \\
(9)\end{array}$ & $\begin{array}{l}\text { Ordered probit } \\
\text { (happy) } \\
\text { (10) }\end{array}$ & $\begin{array}{l}\text { Ordered probit } \\
\text { (happy) } \\
\text { (11) }\end{array}$ & $\begin{array}{l}\text { Ordered probit } \\
\text { (happy) } \\
\text { (12) }\end{array}$ \\
\hline \multicolumn{13}{|l|}{$\begin{array}{l}\text { All respondents (Panel A) } \\
\text { (a) }\end{array}$} \\
\hline Non-single-mother time trend & $-0.033(0.090)$ & $-0.049(0.123)$ & $-0.176(0.105) *$ & $0.049(0.099)$ & $-0.193(0.139)$ & $-0.148(0.156)$ & $-0.298(0.146) * *$ & $-0.219(0.141)$ & $-0.372(0.274)$ & $-0.651(0.260) * *$ & $-0.795(0.243) * * *$ & $-0.795(0.243) * * *$ \\
\hline Single-mother time trend & $0.447(0.247) *$ & $0.477(0.245) *$ & $0.258(0.212)$ & $0.258(0.217)$ & $0.446(0.246) *$ & $0.524(0.255) * *$ & $0.308(0.225)$ & $0.291(0.229)$ & $0.458(0.252) *$ & $0.094(0.186)$ & $-0.158(0.206)$ & $-0.158(0.206)$ \\
\hline Difference in time trend & $0.480(0.222) * *$ & $0.526(0.245) * *$ & $0.434(0.189) * *$ & $0.209(0.185)$ & $0.638(0.257) * *$ & $0.672(0.269) * *$ & $0.606(0.219) * * *$ & $0.510(0.221) * *$ & $0.829(0.191) * * *$ & $0.745(0.186) * * *$ & $0.637(0.237) * * *$ & $0.637(0.237) * * *$ \\
\hline \multicolumn{13}{|l|}{ Trend for divorced respondents (Panel B) } \\
\hline Non-single-mother time trend & $-1.941(0.195) * * *$ & $-1.964(0.195) * * *$ & $-1.805(0.185) * * *$ & $-0.210(0.225)$ & $-2.038(0.245) * * *$ & $-2.033(0.249) * * *$ & $-1.795(0.215) * * *$ & $-0.550(0.326) *$ & $-0.701(0.353) * *$ & $-0.825(0.378) * *$ & $-0.950(0.286) * * *$ & $-0.950(0.286) * * *$ \\
\hline Single-mother time trend & $0.322(0.316)$ & $0.090(0.290)$ & $0.121(0.318)$ & $0.230(0.320)$ & $0.320(0.314)$ & $0.230(0.301)$ & $0.268(0.318)$ & $0.330(0.324)$ & $0.327(0.321)$ & $-0.007(0.258)$ & $-0.098(0.291)$ & $-0.098(0.291)$ \\
\hline Difference in time trend & $2.263(0.311) * * *$ & $2.054(0.320) * * *$ & $1.926(0.333) * * *$ & $0.439(0.357)$ & $2.358(0.347) * * *$ & $2.263(0.365) * * *$ & $2.063(0.320) * * *$ & $0.880(0.368) * *$ & $1.028(0.411) * *$ & $0.818(0.428) *$ & $0.852(0.368) * *$ & $0.852(0.366) * *$ \\
\hline \multicolumn{13}{|l|}{ Trend for separated respondents (Panel C) } \\
\hline Non-single-mother time trend & $-3.142(0.398) * * *$ & $-2.910(0.389) * * *$ & $-2.880(0.311) * * *$ & $-1.294(0.315) * * *$ & $-2.932(0.430) * * *$ & $-2.707(0.439) * * *$ & $-2.902(0.360) * * *$ & $-1.742(0.432) * * *$ & $-1.741(0.431) * * *$ & $-1.681(0.398) * * *$ & $-2.228(0.450) * * *$ & $-2.228(0.450) * * *$ \\
\hline Single-mother time trend & $0.660(0.678)$ & $0.240(0.608)$ & $-0.200(0.655)$ & $-0.039(0.664)$ & $0.656(0.673)$ & $0.449(0.653)$ & $-0.033(0.683)$ & $0.057(0.693)$ & $0.668(0.687)$ & $0.098(0.597)$ & $-0.565(0.700)$ & $-0.565(0.700)$ \\
\hline Difference in time trend & $3.802(0.919) * * *$ & $3.150(0.876)^{* * *}$ & $2.679(0.814) * * *$ & $1.255(0.766)$ & $3.589(0.883) * * *$ & $3.156(0.865) * * *$ & $2.868(0.772) * * *$ & $1.799(0.744) * *$ & $2.410(0.830) * * *$ & $1.779(0.764)^{* *}$ & $1.663(0.837) * *$ & $1.663(0.837) * *$ \\
\hline \multicolumn{13}{|l|}{ Trend for never married respondents (Panel D) } \\
\hline Non-single-mother time trend & $-1.382(0.129) * * *$ & $-1.196(0.162) * * *$ & $-1.084(0.190) * * *$ & $0.120(0.244)$ & $-1.382(0.163)$ & $-1.222(0.198) * * *$ & $-1.184(0.227) * * *$ & $-0.167(0.320)$ & $-0.073(0.284)$ & $-0.390(0.270)$ & $-0.722(0.259) * * *$ & $-0.722(0.259) * * *$ \\
\hline Single-mother time trend & $0.608(0.440)$ & $0.339(0.432)$ & $0.260(0.510)$ & $0.382(0.517)$ & $0.605(0.436)$ & $0.426(0.434)$ & $0.449(0.501)$ & $0.512(0.509)$ & $0.618(0.446)$ & $0.382(0.462)$ & $0.271(0.474)$ & $0.271(0.474)$ \\
\hline Difference in time trend & $1.991(0.461) * * *$ & $1.535(0.473) * * *$ & $1.343(0.560) * *$ & $0.262(0.541)$ & $1.987(0.436) * * *$ & $1.649(0.457) * * *$ & $1.634(0.551) * * *$ & $0.678(0.531)$ & $0.691(0.420) *$ & $0.772(0.407) *$ & $0.994(0.477) * *$ & $0.994(0.477) * *$ \\
\hline Observations $\wedge$ & 26,005 & 26,005 & 24,139 & 24,139 & 14,232 & 14,232 & 13,134 & 13,134 & 6,422 & 6,422 & 5,837 & 5,837 \\
\hline Exogenous control variables included & No & Yes & Yes & Yes & No & Yes & Yes & Yes & No & Yes & Yes & Yes \\
\hline Endogenous control variables except single included & No & No & Yes & Yes & No & No & Yes & Yes & No & No & Yes & Yes \\
\hline Single included & No & No & No & Yes & No & No & No & Yes & No & No & No & Yes \\
\hline
\end{tabular}

$\wedge$ Weighted number of observations. 1,866 respondents are missing income data. If the quartic in log real income per equivalent is dropped from the ordered probit and all other specifications are the same for columns (3) and (4) the results remain similar.

$*$ signifies $\mathrm{p}<=0.10$, ** signifies $\mathrm{p}<=0.05$, and $* *$ signifies $\mathrm{p}<=0.01$ 
Table XIII: Time Trends by Race

\begin{tabular}{|c|c|c|c|c|c|c|c|c|}
\hline & \multicolumn{4}{|c|}{ All respondents } & \multicolumn{4}{|c|}{ Sample restricted to female respondents } \\
\hline & $\begin{array}{l}\text { Ordered probit } \\
\text { (happy) } \\
\text { (1) }\end{array}$ & $\begin{array}{l}\text { Ordered probit } \\
\text { (happy) } \\
\text { (2) }\end{array}$ & $\begin{array}{l}\text { Ordered probit } \\
\text { (happy) } \\
\text { (3) }\end{array}$ & $\begin{array}{l}\text { Ordered probit } \\
\text { (happy) } \\
\text { (4) }\end{array}$ & $\begin{array}{l}\text { Ordered probit } \\
\text { (happy) } \\
\text { (5) }\end{array}$ & $\begin{array}{l}\text { Ordered probit } \\
\text { (happy) } \\
\text { (6) }\end{array}$ & $\begin{array}{l}\text { Ordered probit } \\
\text { (happy) } \\
\text { (7) }\end{array}$ & $\begin{array}{l}\text { Ordered probit } \\
\text { (happy) } \\
\text { (8) }\end{array}$ \\
\hline \multicolumn{9}{|l|}{ All respondents (Panel A) } \\
\hline Non-single-mother time trend & $-0.033(0.090)$ & $-0.049(0.123)$ & $-0.176(0.105) *$ & $0.049(0.099)$ & $-0.193(0.139)$ & $-0.148(0.156)$ & $-0.298(0.146) * *$ & $-0.219(0.141)$ \\
\hline Single-mother time trend & $0.447(0.247) *$ & $0.477(0.245) *$ & $0.258(0.212)$ & $0.258(0.217)$ & $0.446(0.246) *$ & $0.524(0.255) * *$ & $0.308(0.225)$ & $0.291(0.229)$ \\
\hline Difference in time trend & $0.480(0.222) * *$ & $0.526(0.245) * *$ & $0.434(0.189) * *$ & $0.209(0.185)$ & $0.638(0.257) * *$ & $0.672(0.269) * *$ & $0.606(0.219) * * *$ & $0.510(0.221) * *$ \\
\hline
\end{tabular}

Trend for Black respondents (Panel B)

\begin{tabular}{|c|c|c|c|c|c|c|c|c|}
\hline Non-single-mother time trend & $-1.224(0.239) * * *$ & $0.545(0.368)$ & $0.336(0.361)$ & $0.660(0.357) *$ & $-1.272(0.360) * * *$ & $0.884(0.526) *$ & $0.594(0.590)$ & $0.791(0.589)$ \\
\hline Single-mother time trend & $0.923(0.344) * * *$ & $0.843(0.370) * *$ & $0.626(0.326) *$ & $0.641(0.331) *$ & $0.920(0.343) * * *$ & $0.879(0.380) * *$ & $0.666(0.320) * *$ & $0.653(0.326) * *$ \\
\hline Difference in time trend & $2.146(0.371) * * *$ & $0.297(0.435)$ & $0.290(0.408)$ & $-0.019(0.404)$ & $2.192(0.481) * * *$ & $-0.005(0.700)$ & $0.071(0.654)$ & $-0.137(0.659)$ \\
\hline
\end{tabular}

Trend for White respondents (Panel C)

\begin{tabular}{|c|c|c|c|c|c|c|c|c|}
\hline Non-single-mother time trend & $0.391(0.100) * * *$ & $-0.125(0.119)$ & $-0.250(0.107) * *$ & $-0.042(0.106)$ & $0.301(0.151) * *$ & $-0.280(0.145) *$ & $-0.384(0.141) * * *$ & $-0.327(0.140) * *$ \\
\hline Single-mother time trend & $0.372(0.296)$ & $0.291(0.268)$ & $0.131(0.240)$ & $0.141(0.244)$ & $0.370(0.294)$ & $0.330(0.281)$ & $0.139(0.269)$ & $0.126(0.270)$ \\
\hline Difference in time trend & $-0.019(0.296)$ & $0.416(0.298)$ & $0.381(0.213) *$ & $0.182(0.216)$ & $0.069(0.337)$ & $0.610(0.299) * *$ & $0.523(0.239) * *$ & $0.453(0.242) *$ \\
\hline 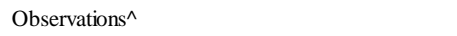 & 26,005 & 26,005 & 24,139 & 24,139 & 14,232 & 14,232 & 13,134 & 13,134 \\
\hline Exogenous control variables included & No & Yes & Yes & Yes & No & Yes & Yes & Yes \\
\hline Endogenous control variables except single included & No & No & Yes & Yes & No & No & Yes & Yes \\
\hline Single included & No & No & No & Yes & No & No & No & Yes \\
\hline
\end{tabular}

$\wedge$ Weighted number of observations. 1,866 respondents are missing income data. If the quartic in log real income per equivalent is dropped from the ordered probit and all other specifications are the same for columns (3) and (4) the

$*$ signifies $\mathrm{p}<=0.10, * *$ signifies $\mathrm{p}<=0.05$, and $* * *$ signifies $\mathrm{p}<=0.01$ 
Table XIV: Time Trends by Age Category

\begin{tabular}{|c|c|c|c|c|c|c|c|c|}
\hline & \multicolumn{4}{|c|}{ All respondents } & \multicolumn{4}{|c|}{ Sample restricted to female respondents } \\
\hline & $\begin{array}{l}\text { Ordered probit } \\
\text { (happy) } \\
\text { (1) }\end{array}$ & $\begin{array}{l}\text { Ordered probit } \\
\text { (happy) } \\
\text { (2) }\end{array}$ & $\begin{array}{l}\text { Ordered probit } \\
\text { (happy) } \\
\text { (3) }\end{array}$ & $\begin{array}{l}\text { Ordered probit } \\
\text { (happy) } \\
\text { (4) }\end{array}$ & $\begin{array}{l}\text { Ordered probit } \\
\text { (happy) } \\
\text { (5) }\end{array}$ & $\begin{array}{l}\text { Ordered probit } \\
\text { (happy) } \\
\text { (6) }\end{array}$ & $\begin{array}{l}\text { Ordered probit } \\
\text { (happy) } \\
\text { (7) }\end{array}$ & $\begin{array}{l}\text { Ordered probit } \\
\text { (happy) } \\
\text { (8) }\end{array}$ \\
\hline \multicolumn{9}{|l|}{ All respondents (Panel A) } \\
\hline Non-single-mother time trend & $-0.033(0.090)$ & $-0.049(0.123)$ & $-0.176(0.105) *$ & $0.049(0.099)$ & $-0.193(0.139)$ & $-0.148(0.156)$ & $-0.298(0.146) * *$ & $-0.219(0.141)$ \\
\hline Single-mother time trend & $0.447(0.247) *$ & $0.477(0.245) *$ & $0.258(0.212)$ & $0.258(0.217)$ & $0.446(0.246) *$ & $0.524(0.255) * *$ & $0.308(0.225)$ & $0.291(0.229)$ \\
\hline Difference in time trend & $0.480(0.222) * *$ & $0.526(0.245) * *$ & $0.434(0.189) * *$ & $0.209(0.185)$ & $0.638(0.257) * *$ & $0.672(0.269) * *$ & $0.606(0.219) * * *$ & $0.510(0.221) * *$ \\
\hline
\end{tabular}

Trends for respondents between 18 and 26 years old (Panel B)

\begin{tabular}{lllllllll} 
Non--single-mother time trend & $-0.514(0.113) * * *$ & $-0.020(0.175)$ & $-0.075(0.181)$ & $0.225(0.172)$ & $-0.660(0.180) * * *$ & $-0.193(0.217)$ & $-0.178(0.210)$ & $0.022(0.193)$ \\
Single-mother time trend & $0.502(0.520)$ & $0.533(0.494)$ & $0.152(0.488)$ & $0.147(0.447)$ & $0.501(0.518)$ & $0.549(0.495)$ & $0.265(0.471)$ & $0.233(0.470)$ \\
\hline Difference in time trend & $1.016(0.477) * *$ & $0.553(0.472)$ & $0.227(0.414)$ & $-0.077(0.418)$ & $1.161(0.459) * *$ & $0.742(0.432) *$ & $0.444(0.375)$ & $0.211(0.373)$ \\
\hline
\end{tabular}

Trend for respondents between 27 and 36 years old (Panel C)

\begin{tabular}{lllllllll} 
Non-single-mother time trend & $0.228(0.106) * * * *$ & $0.020(0.147)$ & $-0.088(0.119)$ & $0.144(0.119)$ & $0.093(0.169)$ & $-0.066(0.219)$ & $-0.198(0.179)$ & $-0.144(0.177)$ \\
Single-mother time trend & $0.629(0.466)$ & $0.602(0.479)$ & $0.374(0.460)$ & $0.374(0.461)$ & $0.627(0.435)$ & $0.645(0.477)$ & $0.411(0.450)$ & $0.392(0.488)$ \\
\hline Difference in time trend & $0.401(0.46)$ & $0.582(0.483)$ & $0.462(0.434)$ & $0.229(0.428)$ & $0.534(0.493)$ & $0.711(0.550)$ & $0.609(0.491)$ & $0.535(0.489)$ \\
\hline
\end{tabular}

Trend for respondents between 37 and 45 years old (Panel D)

\begin{tabular}{|c|c|c|c|c|c|c|c|c|}
\hline Non-single-mother time trend & $0.083(0.102)$ & $-0.171(0.174)$ & $-0.393(0.187) * *$ & $-0.238(0.175)$ & $-0.738(0.084) * * *$ & $-0.216(0.204)$ & $-0.544(0.266) * *$ & $-0.541(0.258) * * *$ \\
\hline Single-mother time trend & $0.170(0.452)$ & $0.316(0.437)$ & $0.209(0.333)$ & $0.208(0.336)$ & $-0.126(0.151)$ & $0.381(0.440)$ & $0.213(0.372)$ & $0.205(0.375)$ \\
\hline Difference in time trend & $0.088(0.429)$ & $0.486(0.481)$ & $0.602(0.370)$ & $0.446(0.361)$ & $0.296(0.457)$ & $0.598(0.493)$ & $0.758(0.403) *$ & $0.746(0.393) *$ \\
\hline Observations^ & 26,005 & 26,005 & 24,139 & 24,139 & 14,232 & 14,232 & 13,134 & 13,134 \\
\hline Exogenous control variables included & No & Yes & Yes & Yes & No & Yes & Yes & Yes \\
\hline Endogenous control variables except single included & No & No & Yes & Yes & No & No & Yes & Yes \\
\hline Single included & No & No & No & Yes & No & No & No & Yes \\
\hline
\end{tabular}

$\wedge$ Weighted number of observations. 1,866 respondents are missing income data. If the quartic in log real income per equivalent is dropped from the ordered probit and all other speciifations are the same for columns (3) and (4) the $*$ signifies $\mathrm{p}<=0.10, * *$ siginifies $\mathrm{p}<=0.05$, and $* * *$ signifies $\mathrm{p}<=0.01$ 
Figure I: Happiness Trends (1972 - 2008)

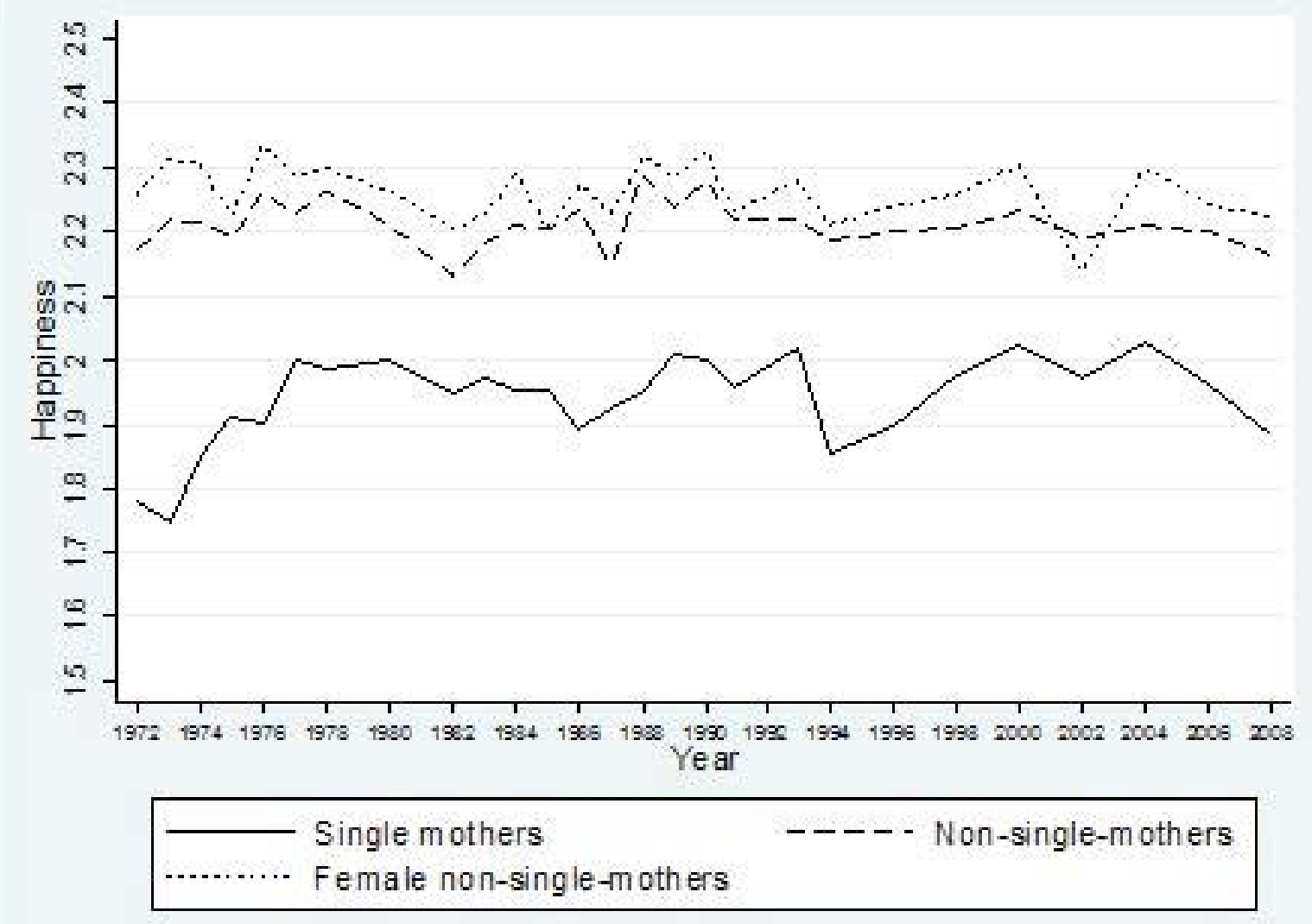

